\title{
Paleomagnetic tracking of mountain building in the Peruvian Andes since $10 \mathrm{Ma}$
}

\author{
Sonia Rousse, ${ }^{1}$ Stuart Gilder, ${ }^{1}$ Daniel Farber, ${ }^{2}$ Brendan McNulty, ${ }^{3}$ Philippe Patriat, ${ }^{1}$ \\ Victor Torres, ${ }^{4}$ and Thierry Sempere ${ }^{5}$
}

Received 29 January 2003; revised 2 June 2003; accepted 12 June 2003; published 23 September 2003.

[1] We report paleomagnetic data from 73 sites $(628$ samples) of upper Oligocene to Pliocene rocks from central and northern Peru. The data indicate that the Subandean Zone has not experienced vertical axis rotation since the upper Oligocene, whereas the coast and the Western Cordillera record a coherent pattern of counterclockwise rotations emplaced in the last $10 \mathrm{Ma}$. This pattern can best be explained by two competing hypotheses: (1) a propagation in rotations from the Bolivian Orocline toward the north or (2) a more punctual and widespread event linked to subduction of the Nazca Ridge that caused the rotations. On the basis of the time-space relationship of paleomagnetic rotations, deformation, magmatism and Nazca-South America plate convergence, the latter appears more likely. Moreover, because the rotations north of the Abancay deflection $\left(\sim 15.5^{\circ} \mathrm{S}\right)$ are synchronous with deformation and exhumation, they indicate that major mountain building in the Peruvian Andes has occurred since $10 \mathrm{Ma}$. Finally, we suggest that a succession of aseismic ridge subduction events played an important role in shaping the modern topography of the Andean chain. INDEX TERMS: 1525 Geomagnetism and Paleomagnetism: Paleomagnetism applied to tectonics (regional, global); 8155 Tectonophysics: Plate motions-general; 8102 Tectonophysics: Continental contractional orogenic belts; 9360 Information Related to Geographic Region: South America; 9604 Information Related to Geologic Time: Cenozoic; KEYWORDS: paleomagnetism, Andes, Peru, Cenozoic, South America, Nazca. Citation: Rousse, S., S. Gilder, D. Farber, B. McNulty, P. Patriat, V. Torres, and T. Sempere, Paleomagnetic tracking of mountain building in the Peruvian Andes since $10 \mathrm{Ma}$, Tectonics, 22(5), 1048, doi:10.1029/2003TC001508, 2003.

\footnotetext{
${ }^{1}$ Laboratoire de Paléomagnétisme, Institut de Physique du Globe de Paris, Paris, France.

${ }^{2}$ Lawrence Livermore National Laboratory, Livermore, California, USA.

${ }^{3}$ Earth Science Department, California State University, Dominguez Hills, Carson, California, USA.

${ }^{4}$ Instituto Geológico, Minero y Metalúrgico (INGEMMET), Lima, Peru.

${ }^{5}$ Institut de Recherche pour le Développement (IRD), Lima, Peru.

Copyright 2003 by the American Geophysical Union. 0278-7407/03/2003TC001508
}

\section{Introduction}

[2] The Andes span the length of the western margin of the South American plate constituting one of the world's longest and highest mountain ranges (Figure 1, inset). The chain is the widest around $19^{\circ} \mathrm{S}$ where the Earth's second largest plateau, the Altiplano, is situated, then progressively narrows to the south and north. The Altiplano region is also marked by progressive reorientation in regional structural trends that define a distinct bend known as the Arica deflection or Bolivian Orocline. Paleomagnetic studies in the Andes since the 1970's have identified a fairly consistent pattern of rotations, mainly counterclockwise north of the Arica deflection and clockwise to its south, that vary systematically in concert with reorientation of the strike of geologic structures. One of the earliest and most comprehensive hypotheses to explain the link between deformation, the pattern of paleomagnetic rotations and mountain building was proposed by Isacks [1988]. Following the orocline model of Carey [1955], Isacks [1988] suggested that the South American margin was originally curved like today, although less concave toward the Nazca Plate. Then, beginning at circa $15 \mathrm{Ma}$, the curvature became enhanced via an along strike gradient in crustal shortening that attained a maximum at the Arica deflection. This resulted in generating the observed topography, rotation sense and change in structural trends. Since 1988, the paleomagnetic database has greatly increased and generally corroborates earlier findings that changes in paleomagnetic rotations coincide with changes in structural trends along the Andean chain. However, complexities surrounding the timing and length scales of the rotations have led to a suite of block models [Beck, 1988; Aubry et al., 1996; Randall et al., 1996, 2001; Somoza et al., 1996; Somoza and Tomlinson, 2002; Abels and Bischoff, 1999; Lamb, 2001], some of which might argue against a direct link between deformation, paleomagnetic rotation and mountain building.

[3] Paleomagnetism can be used to distinguish between competing models, if one can unambiguously identify the timing and spatial extent of the block rotations. For example, are the rotations coeval throughout the length of the Andes, or is there an age gradient along the length and/or width of the chain? Is the rotation pattern due to one or more discrete deformation pulses or does it result from a continuous deformation process? An obstacle to answer these questions arises from the fact that deformation may not be distributed homogenously, and thus paleomagnetic rotations may not be rotated uniformly. For example, in some localities in the Andes (e.g., $22.5^{\circ} \mathrm{S}, 291.5^{\circ} \mathrm{E}$ ), Mesozoic rocks appear more 


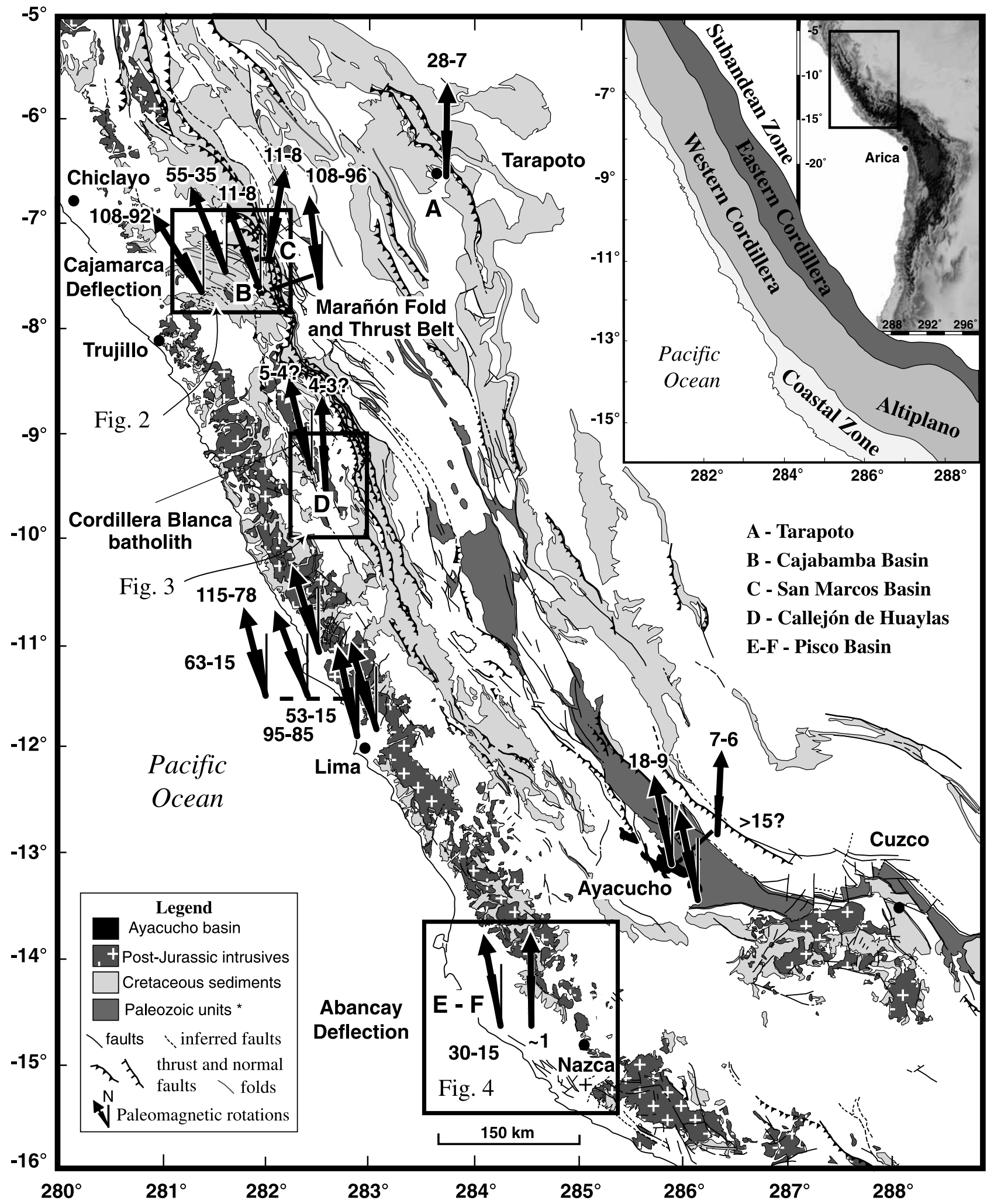

Figure 1. Simplified geologic map of the Peruvian Andes between $5^{\circ}$ and $16^{\circ} \mathrm{S}$ [after Instituto de Geologia y Mineria, 1975]. Asterisk indicates distribution of Paleozoic rocks has been simplified. Paleomagnetic sampling localities are shown. A to F refers to the data in Table 3. Inset: Topographic map of the Andes ( $>4,000 \mathrm{~m}$ in black) and major morphotectonic provinces (see text). 
rotated than those of Cenozoic age [Butler et al., 1995; Somoza and Tomlinson, 2002], whereas around $27^{\circ} \mathrm{S}$, $294^{\circ} \mathrm{E}$, the opposite is observed-younger rocks are more rotated [Aubry et al., 1996]. In coastal northern Chile, Roperch et al. [2000] reports no significant rotation $\left(0.3^{\circ} \pm\right.$ $6.9^{\circ}$ ) in nine lower Miocene (23-19 Ma) ignimbrite flows, while $\sim 2^{\circ}$ farther north, pre-late Oligocene rocks from the southern margin of Peru are rotated $\sim 30^{\circ}$ counterclockwise, suggesting rotation occurred before the early Miocene in the coastal area. Upper Miocene rocks located farther inland in the Cordillera are clockwise rotated [Roperch et al., 1999], which led Roperch et al. [2000] to propose that the forearc first deformed/rotated in the late Oligocene, then became rigidly coupled to the subducting plate and indented and deformed the region farther inland in the Miocene.

[4] One might further question whether the processes responsible for the formation of the Bolivian Orocline are valid for the entire Andean chain. The Isacks [1988] model, subsequently treated by Gephart [1994], explains the symmetry of the Bolivian Orocline but does not address mountain building processes north of the Abancay deflection at $\sim 15^{\circ} \mathrm{S}$. In central Peru, Rousse et al. [2002] presented paleomagnetic data from 31 Neogene sites in the Ayacucho basin. Strata dated from 18 to 9 Ma recorded a significant counterclockwise rotation $\left(-11^{\circ} \pm 5^{\circ}\right)$, whereas unconformably overlying 7 to 6 Ma strata were not rotated. The age of rotation and compressive deformation thus took place between 9 and $7 \mathrm{Ma}$. Moreover, eight independent studies on 107 to $9 \mathrm{Ma}$ rocks from Peru collected between $11^{\circ} \mathrm{S}$ and $15^{\circ} \mathrm{S}$ (north of the Abancay deflection, Figure 1) reveal similar and significant counterclockwise rotations $\left(-15^{\circ} \pm 6^{\circ}\right)$ [cf. Rousse et $a l ., 2002]$. This suggests that the region rotated during a $2 \mathrm{Myr}$ period of deformation at circa $8 \mathrm{Ma}$; therefore, unlike in the oroclinal section of the chain, paleomagnetic rotations in central Peru seem to be coherent over a broad area and punctual in time.

[5] To further investigate this pattern of Neogene paleomagnetic rotations in northern and central Peru, we carried out a paleomagnetic study in three Neogene intracordilleran basins as well as in the Subandean and Coastal zones. Our new data reinforce earlier findings of post- $10 \mathrm{Ma}$, counterclockwise rotations, expanded now to an area from $7^{\circ} \mathrm{S}$ to $15.5^{\circ} \mathrm{S}$. Furthermore, the new data allow for significant refinement of the time-space relationship of the rotations in this vast region. To understand the origin of these rotations, we reconstruct Nazca-South American plate motion for the last $20 \mathrm{Ma}$. Our reconstructions show that convergence direction and velocity changed during the late Miocene, coincident with the initiation of subduction of the Nazca Ridge, potentially explaining the timing of the paleomagnetic rotations we observe. Lastly, we discuss the geodynamic implications of the rotations and associated deformation.

\section{Geologic Setting and Paleomagnetic Sampling}

[6] The recognized morphotectonic domains of Peru strike NNW and, from west to east, comprise the Coastal Zone, the Western Cordillera, the Eastern Cordillera and the
Subandean Zone (Figure 1, inset). The Coastal Zone is a few to tens of kilometers wide and consists mostly of volcanoclastic and shallow marine sediments. In the western part of the Western Cordillera, Late Jurassic to Cretaceous sediments are covered by gently folded Albian pillow lava, tuff and limestone [Cobbing et al., 1981]. These were intruded by the Coastal Batholith between 82 and $34 \mathrm{Ma}$, which is in turn overlain, or cut by, Eocene to Miocene volcanics known as the Calipuy Group [Pitcher and Cobbing, 1985]. East of the Coastal Batholith, the Western Cordillera is mainly composed of strongly folded Mesozoic sediments [Audebaud et al., 1973]. In northern Peru, the transition between the Western and Eastern Cordillera is demarcated by a dense series of imbricated thrust sheets called the Marañón fold and thrust belt [Mégard, 1984] (Figure 1). The Eastern Cordillera contains Paleozoic metamorphic, igneous and sedimentary rocks of variable proportion. Farther east are folded Mesozoic to Cenozoic sediments of the Subandean Zone. Samples reported in this study come from the Western Cordillera, the Subandean Zone, and from the Coastal Zone (Figure 1).

\subsection{Subandean Zone}

[7] In northern and central Peru, the Subandean Zone represents a thin-skinned fold and thrust belt that initiated during the upper Miocene (circa $11 \mathrm{Ma}$ ) [Audebaud et al., 1973; Noble and McKee, 1977] and is active today as evidenced by high levels of crustal seismicity [Jordan et al., 1983; Dorbath, 1996]. In the Tarapoto region (Figure 1) at $200 \mathrm{~m}$ altitude, we sampled ten sites of Cenozoic sediments that crop out principally near the heart of a NNW-striking syncline. We drilled 3 sites (28 cores) in the Chambira Formation and 7 sites (62 cores) in the Ipururo Formation. The Chambira Formation is constrained in age as upper Oligocene to lower Miocene by fossils found in the lower part of the section such as Trochamminas sp., Haplophragmoides sp. and Ammobaculites sp., and in the upper part of the section by Peckichara alejandroensis n. sp., Kosmogyra shiringaensis Bliss, Tectochara ucayaliensis Bliss, Tectochara ucayaliensis coronata Bliss, Tectochara ucayaliensis principalis Bliss, Tectochara ucayaliensis oblonga Bliss, and Tectochara parva Bliss [Gutiérrez, 1975]. Its lithology is mainly composed of fine-grained sandstone, probably deposited in a lagoonal environment. The Ipururo Formation is comprised mostly of sandstone and siltstone, with intercalated conglomerates and breccia. Around Tarapoto, a MioPliocene age is suggested for this formation because it stratigraphically overlies the Oligo-Miocene Chambira Formation and underlies the inferred Pliocene to recent Ucayali conglomerates. The Ipururo Formation is stratigraphically correlated with outcrops in Moyobamba, $50 \mathrm{~km}$ to the west, dated as Miocene based on the presence of charophytes Tectochara ucayaliensis n. sub. sp., Tectochara ucayaliensis B. sp. and Charites neshuyaensis B. sp. [Sánchez and Herrera, 1998].

\subsection{Miocene Intracordilleran Basins}

[8] Several Mio-Pliocene basins crop out along strike of the Western Cordillera in northern and central Peru. Those 

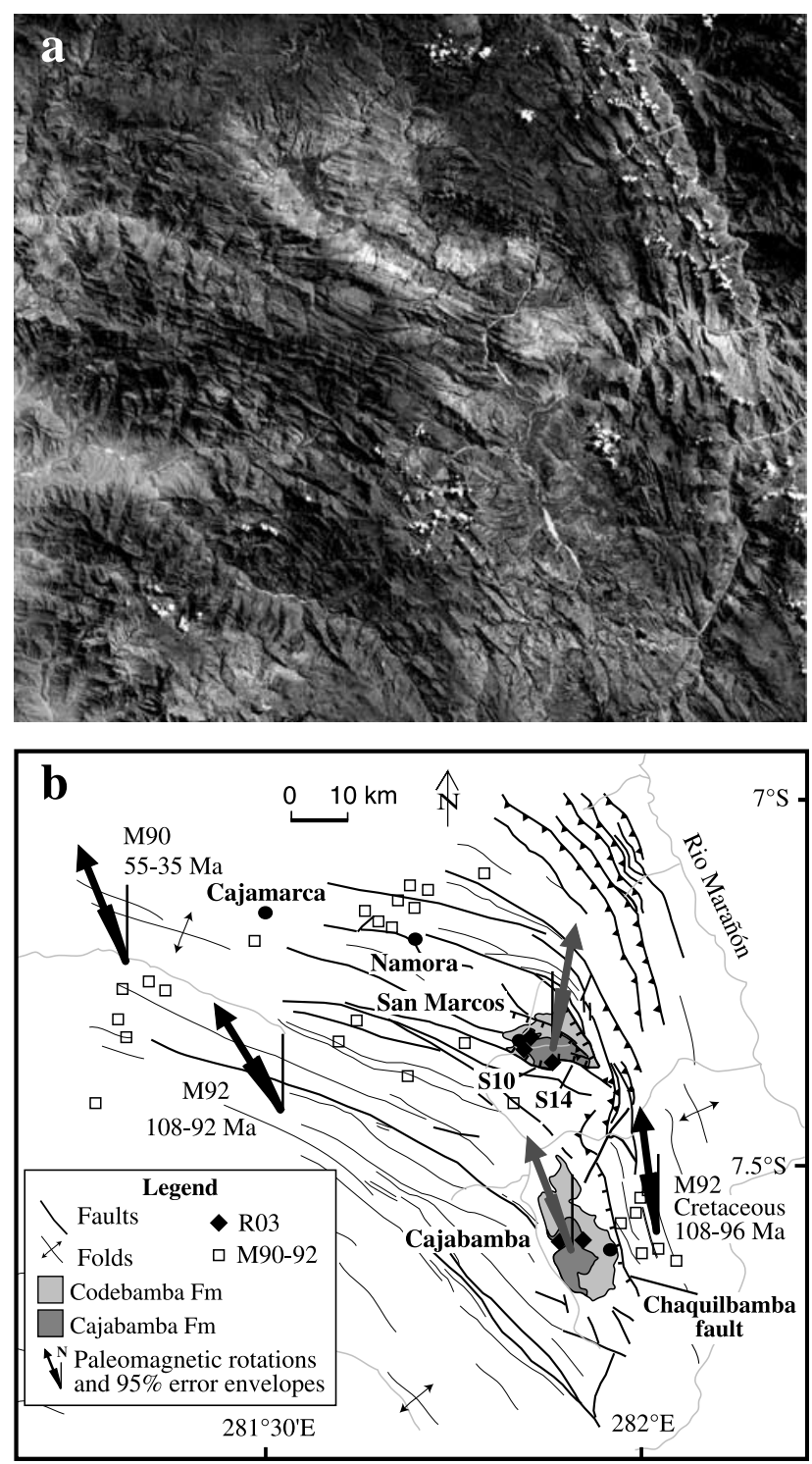

C
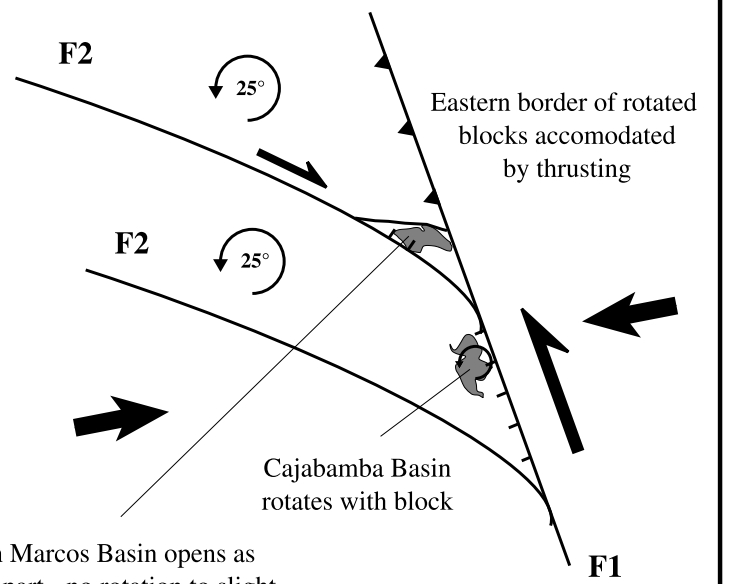

San Marcos Basin opens as

pull apart - no rotation to slight

clockwise rotation under

influence of F2 faults north of $\sim 11^{\circ} \mathrm{S}$ formed in a tectonic regime dominated by extension [Bonnot et al., 1988; Bellier et al., 1989; Mercier et al., 1992]. Below we describe three of these basins (Cajabamba, San Marcos and Callejón de Huaylas) from which we collected 236 paleomagnetic samples.

\subsubsection{Cajamarca Deflection: Cajabamba and} San Marcos Basins

[9] Both the Cajabamba and San Marcos basins lie within the Cajamarca deflection, which is an enigmatic structural feature of the northern Peruvian Andes, easily identified on Landsat images as a change in the trend of regional-scale folds that strike E-W in the west and NNW in the east (Figures 1 and 2). Within the deflection, around $6.5^{\circ} \mathrm{S}$ and $281^{\circ} \mathrm{E}$, the age of folding was constrained between 44 and 39 Ma because folded rocks below an observed angular unconformity yielded $\mathrm{K}-\mathrm{Ar}$ dates as young as $44.2 \mathrm{Ma}$ while those above gave $39 \mathrm{Ma}(\mathrm{Ar} / \mathrm{Ar})$ to $35.4 \mathrm{Ma}(\mathrm{K}-\mathrm{Ar})$ dates [Noble et al., 1990]. Other deformation events in the region have been recognized during the Oligo-Miocene and thereafter, but their relative importance on the development of the Cajamarca deflection is unclear [e.g., Sébrier et al., 1988]. An extensive paleomagnetic study of the Cajamarca deflection by Mitouard et al. [1990, 1992] of 51 sites on rocks spanning ages from 108 to 35 Ma show a pattern of coherent paleomagnetic rotations that are uncorrelated with fold axis trends (Figure 2b). Seven sites of Cretaceous rocks from a limited area east of Cajabamba were found to be unrotated (Figure 2b). From their study, Mitouard et al. [1992] concluded that the shape of the Cajamarca deflection involved the building of arcuate structures in the PaleoceneEocene via a nonrotational mechanism, followed by relative rotation between the bulk of the structure with respect to the eastern Cajabamba area after the late Eocene (37 Ma). Thus the age of the paleomagnetic rotations was concluded to postdate the late Eocene.

[10] Within the Cajamarca deflection lie four basins of Neogene age [Bellier et al., 1989] from which we drilled 8 sites (62 cores) in the Cajabamba basin and 8 sites (74 cores) in the San Marcos basin (Figures 2a and 2b); we attempted to collect samples from the Namora basin (around Namora city, Figure 2b) but were unsuccessful due to very limited outcrops and extremely unconsolidated sediments. The Cajabamba basin lies in the SE part of the Cajamarca deflection where Cretaceous fold axes change their orientation from $\mathrm{W}$ to NNW. About $40 \mathrm{~km}$ north of the Cajabamba basin is the San Marcos basin, which is situated at the limit between the structures defining the Cajamarca

Figure 2. (opposite) (a) Landsat image of the Cajamarca deflection (see Figure 1 for location). (b) Simplified structural and geological map of the same area as in Figure 2a; Paleomagnetic rotations are from the data in Table 3 and Mitouard et al. [1990, 1992] (M90 and M92, respectively); open squares mark the Cretaceous paleomagnetic sites from Mitouard et al. [1992] (M92); solid diamonds mark the sites from this study (R03). (c) Simplified tectonic model explaining the pattern of rotations observed in the Cajamarca deflection (see text). 


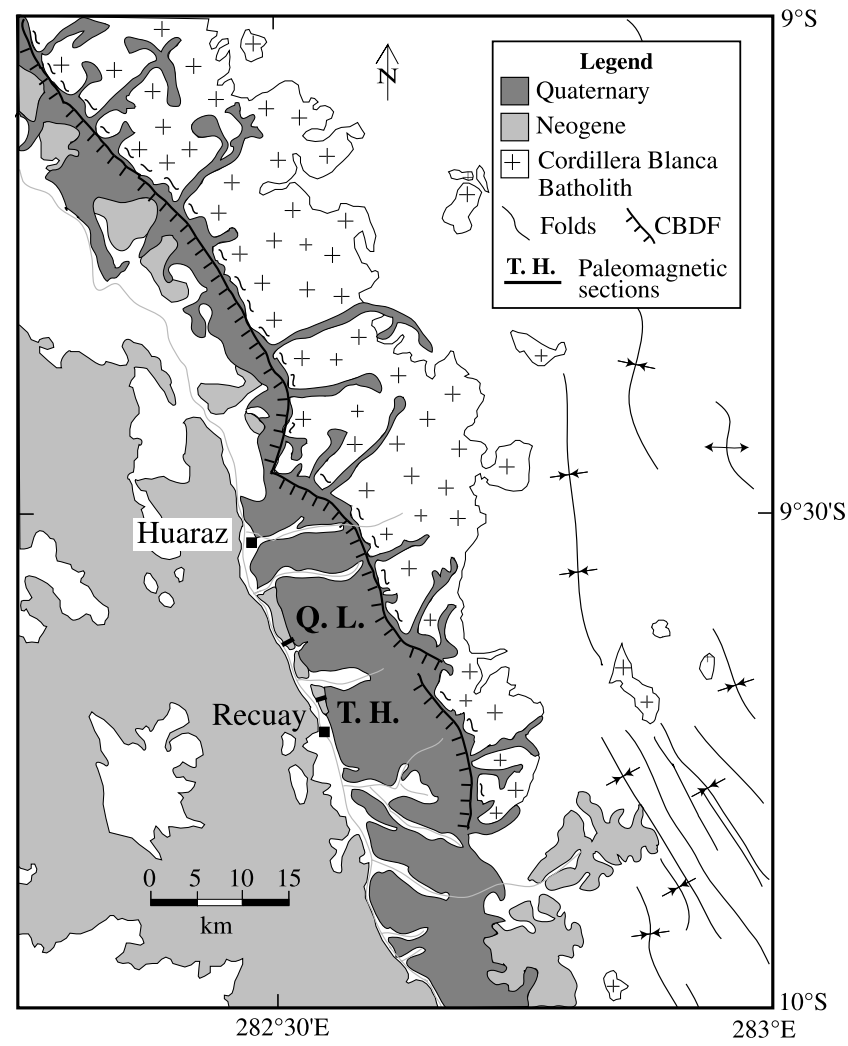

Figure 3. Simplified geological map of the Callejón de Huaylas [Wilson et al., 1995; Cobbing et al., 1996] showing the Cordillera Blanca detachment fault (CBDF) and the two paleomagnetic sections, Quebrada Lloclla (Q.L.) and Telar Huain (T.H.), sampled in this study.

deflection to the west and the Marañón thrust belt to the east (Figure 2b). From fault slip analyses, Bellier et al. [1989] suggested that these basins formed as half grabens that developed in a tectonic regime dominated by ENE-trending extension.

[11] Both basins were filled with 1000 to $1300 \mathrm{~m}$ thick fluvial and fluvio-lacustrine Neogene sediments, called the Cajabamba Formation, that were deposited over folded Upper Jurassic and Cretaceous strata. Covering the Cajabamba Formation are the fluvio-torrential deposits of the 350 to $500 \mathrm{~m}$ thick Codebamba Formation. The Cajabamba Formation lithologies include sandstone, shale, marl, gypsum and diatomite. The presence of the diatom Mesodictyon sp. constrains the maximum age as $11 \mathrm{Ma}$, by correlation with the age of the first occurrence of this species in North America strata [Fourtanier et al., 1993]. This age is also suggested by the occurrence of Cyclotella, which is dated at about $11 \mathrm{Ma}$ in the western United States. On the basis of these considerations, Fourtanier et al. [1993] attributed the diatomite layers in the upper part of the Cajabamba Formation to be 11-10 Ma, concordant with a middle to upper Miocene age deduced from Melosira aff. agassizi and other species that are similar to the Russian Miocene Aveolophora jouseana [Bellier et al., 1989]. Thus the biostratigraphic evidence indicates deposition at circa $11 \mathrm{Ma}$. Volcanic tuff and synsedimentary faults found within the basin suggest that volcanism and tectonism were active during sedimentation [Bellier et al., 1989; Mercier et al., 1992], coeval with a phase of Andean uplift in this region from 11 to $8 \mathrm{Ma}$ as proposed by Mourier [1988] and Noble et al. [1990].

\subsubsection{Callejón de Huaylas Basin}

[12] The Callejón de Huaylas basin lies west of the Cordillera Blanca batholith, which today forms the highest peaks of the Peruvian Andes (Figure 3). The batholith is composed mainly of granodiorite and tonalite that yielded a concordant U-Pb zircon date of $8.2 \pm 0.2 \mathrm{Ma}$ [McNulty et al., 1998]. On the basis of $\mathrm{K} / \mathrm{Ar}$ and ${ }^{40} \mathrm{Ar} /{ }^{39} \mathrm{Ar}$ dating [Petford and Atherton, 1992], it likely cooled from $500^{\circ} \mathrm{C}$ to $300^{\circ} \mathrm{C}$ in the 5 to $3 \mathrm{Ma}$ window. Its western contact is the spectacular, 1 to $3 \mathrm{~km}$-wide, west dipping Cordillera Blanca detachment fault, which played a major role in the uplift of the batholith and is the largest seismogenic normal-fault zone in the Peruvian Andes. Callejón de Huaylas sediments were deposited on the hanging wall block of the fault. The Yungay tuff, found in the northern part of the basin, presumably marks the start of both the structural control of the basin and the exhumation of the batholith [Bonnot et al., 1988]. K-Ar biotite dates from this tuff range between 7.8 and $6.9 \mathrm{Ma}$ [Farrar and Noble, 1976; Cobbing et al., 1981]. The basin's southern part is filled with the $2000 \mathrm{~m}$ thick Lloclla Formation, from which we sampled two sections at Quebrada Lloclla and Telar Huain (Figure 3). Whole rock K-Ar ages of $5.4 \pm 0.1$ and $4.65 \pm 0.1 \mathrm{Ma}$ were obtained from a tuffaceous horizon at the base of the Lloclla Formation at Quebrada Lloclla and Telar Huain, respectively [Bonnot, 1984]. The tuffaceous horizon at Quebrada Lloclla lies about $15 \mathrm{~m}$ above highly altered volcanic rocks assigned to the Calipuy Formation, upon which the Lloclla Formation sediments were deposited.

[13] The Lloclla Formation is divided into two members [Bonnot et al., 1988]. The lower one ( $650 \mathrm{~m}$ thick) is composed of fluvio-torrential to lacustrine facies including conglomerate, black shale, marl, gypsum horizons, siltstone and sandstone; the overlying member is mainly characterized by conglomeratic and glacio-fluvial fan sequences that were probably deposited during Quaternary glaciation. The orientation of channels and imbricated pebbles suggests that the sediments were shed principally from the east. Bonnot et al. [1988] found that the sedimentary sequence in the lower member was deposited under an active tectonic regime based on the presence of synsedimentary normal faults identified within the basin. Kinematic analyses on these faults indicate they formed under NE directed extension [Bonnot et al., 1988]. Our bedding measurements show shallow dips between $0^{\circ}$ and $22^{\circ}$ dipping toward $\mathrm{N} 60^{\circ} \mathrm{E}$, consistent with ENE-extension. In the field, we identified an angular unconformity within the lower member, with relatively flat lying (dips $<10^{\circ}$ ) beds above the unconformity, while those below dip consistently greater than $10^{\circ}$ (Table 1).

\subsection{Pisco Basin}

[14] The Pisco basin lies just north of where both the coast and structural trends undergo a major reorientation 
Table 1. High Temperature-High Coercivity Paleomagnetic Results From the Subandean Zone and the Western Cordillera ${ }^{a}$

\begin{tabular}{|c|c|c|c|c|c|c|c|c|c|c|c|c|c|}
\hline \multirow[b]{2}{*}{ Site Number } & \multirow[b]{2}{*}{$\lambda s,{ }^{\circ} \mathrm{S}$} & \multirow[b]{2}{*}{$\phi \mathrm{s},{ }^{\circ} \mathrm{W}$} & \multirow{2}{*}{$\begin{array}{c}\text { Average } \\
\text { Strike, Dip }\end{array}$} & \multirow[b]{2}{*}{ no/No } & \multirow[b]{2}{*}{$N / R$} & \multicolumn{4}{|c|}{ Geographic } & \multicolumn{4}{|c|}{ Stratigraphic } \\
\hline & & & & & & $\mathrm{Dg}$ & Ig & $\mathrm{k}$ & $\alpha_{95}$ & Ds & Is & $\mathrm{k}$ & $\alpha_{95}$ \\
\hline \multicolumn{14}{|c|}{ Tarapoto } \\
\hline \multicolumn{14}{|l|}{ Ipururo Formation } \\
\hline P944 & $6^{\circ} 35.14^{\prime}$ & $76^{\circ} 18.17^{\prime}$ & $152.3 / 22$ & 9/9 & $0 / 3$ & 161.4 & 31.6 & 24.8 & 11.1 & 173.2 & 25.8 & 24.8 & 11.1 \\
\hline P945 & $\sim 20 \mathrm{mbe}$ & low P946 & $112 / 29^{\mathrm{b}}$ & $8 / 10$ & $5 / 0$ & 159.7 & 42.2 & 31.3 & 10.3 & 170.2 & 18.8 & 31.3 & 10.3 \\
\hline P946 & $6^{\circ} 34.93^{\prime}$ & $76^{\circ} 18.08^{\prime}$ & $115.6 / 28$ & $10 / 10$ & $0 / 7$ & 162.8 & 55.6 & 25.2 & 10.0 & 178.6 & 32.3 & 25.2 & 10.0 \\
\hline P947 & $6^{\circ} 34.81^{\prime}$ & $76^{\circ} 17.85^{\prime}$ & $286.9 / 35$ & $7 / 8$ & $4 / 0$ & 189.5 & -11.9 & 19.6 & 14.5 & 189.1 & 22.8 & 19.6 & 14.5 \\
\hline P948 & $6^{\circ} 34.81^{\prime}$ & $76^{\circ} 17.85^{\prime}$ & $288.9 / 58^{\mathrm{b}}$ & $5 / 5$ & $0 / 5$ & 169.7 & -32.5 & 16.5 & 19.4 & 173.8 & 16.3 & 22.5 & 16.5 \\
\hline $\mathrm{P} 960^{\mathrm{c}}$ & $6^{\circ} 34.83^{\prime}$ & $76^{\circ} 18.88^{\prime}$ & $125.9 / 44$ & $4 / 10$ & $4 / 0$ & 137.4 & 34.4 & 15.1 & 24.4 & 158.1 & 17.0 & 15.1 & 24.4 \\
\hline P961 & $6^{\circ} 34.83^{\prime}$ & $76^{\circ} 18.88^{\prime}$ & $115.9 / 29^{b}$ & $9 / 10$ & $5 / 0$ & 153.0 & 36.7 & 21.3 & 11.7 & 164.0 & 16.7 & 21.3 & 11.7 \\
\hline Mean & & & & $6 / 7$ & & 165.5 & 44.7 & 2.8 & 49.6 & 174.7 & 22.3 & 65.7 & 8.3 \\
\hline \multicolumn{14}{|c|}{ Chambira Formation } \\
\hline P949 & $6^{\circ} 34.70^{\prime}$ & $76^{\circ} 17.32^{\prime}$ & $188.4 / 26$ & $9 / 10$ & $0 / 3$ & 171.3 & 24.9 & 46.5 & 8.1 & 184.8 & 29.6 & 46.5 & 8.1 \\
\hline P950 & $6^{\circ} 34.84^{\prime}$ & $76^{\circ} 16.68^{\prime}$ & $150.9 / 61$ & 9/9 & $0 / 6$ & 162.0 & 31.2 & 48.5 & 7.6 & 183.3 & 6.2 & 48.5 & 7.6 \\
\hline P951 & $6^{\circ} 34.81^{\prime}$ & $76^{\circ} 16.52^{\prime}$ & $159.9 / 50.5$ & $8 / 9$ & $0 / 5$ & 152.9 & 34.5 & 73.7 & 6.7 & 184.4 & 25.9 & 73.7 & 6.7 \\
\hline Mean & & & & $3 / 3$ & & 162.4 & 30.4 & 75.4 & 14.3 & 184.1 & 20.6 & 41.3 & 19.4 \\
\hline Mean Ipururo & & & & $9 / 10$ & & 165.4 & 25.1 & 7.8 & 19.6 & 177.8 & 21.8 & 53.8 & 7.1 \\
\hline \multicolumn{14}{|c|}{ Cajabamba } \\
\hline P814 & $7^{\circ} 36.00^{\prime}$ & $78^{\circ} 05.00^{\prime}$ & $315.4 / 13$ & $9 / 9$ & $0 / 3$ & 165.6 & 6.9 & 28.0 & 10.5 & 163.5 & 13.3 & 28.0 & 10.5 \\
\hline P815 & $\sim 30 \mathrm{~m}$ be & low P814 & $335.3 / 8$ & $6 / 7$ & $0 / 3$ & 155.4 & 10.2 & 35.0 & 12.3 & 154.0 & 10.1 & 35.0 & 12.3 \\
\hline P816 & $\sim 25 \mathrm{mbe}$ & low P815 & $326.3 / 14$ & $7 / 7$ & $0 / 4$ & 158.5 & 13.7 & 25.8 & 12.6 & 154.9 & 16.2 & 25.8 & 12.6 \\
\hline P817 & $\sim 100 \mathrm{~m} \mathrm{~b}$ & elow P816 & $315.3 / 11$ & $8 / 8$ & $0 / 5$ & 163.8 & 9.6 & 72.3 & 6.8 & 161.7 & 14.6 & 72.3 & 6.8 \\
\hline P818 & $7^{\circ} 36.05^{\prime}$ & $78^{\circ} 06.43^{\prime}$ & $60.8 / 7$ & $6 / 6$ & $6 / 0$ & 149.3 & 16.2 & 128.7 & $\begin{array}{l}0.0 \\
5.9\end{array}$ & 149.3 & $\begin{array}{l}1.0 \\
9.2\end{array}$ & 128.7 & $\begin{array}{l}0.0 \\
5.9\end{array}$ \\
\hline P819 & $\sim 50 \mathrm{~m} \mathrm{ab}$ & ove P818 & $48.7 / 14$ & $6 / 6$ & $4 / 2$ & 160.4 & 29.2 & 19.3 & 15.7 & 158.4 & 16.1 & 19.3 & 15.7 \\
\hline P820 & $\sim 3 \mathrm{~m}$ abo & ve $\mathrm{P} 818$ & $65.3 / 7.5^{\mathrm{b}}$ & $10 / 10$ & $10 / 0$ & 145.6 & 19.4 & 58.5 & 6.4 & 145.9 & 12.0 & 58.5 & 6.4 \\
\hline $\mathrm{P} 821^{\mathrm{c}}$ & $\sim 100 \mathrm{~m} \mathrm{a}$ & jove P818 & $132.8 / 21.5$ & $0 / 9$ & - & - & - & - & - & - & - & - & - \\
\hline Mean & & & & $7 / 8$ & & 157.0 & 15.1 & 61.2 & 7.8 & 155.4 & 13.1 & 141.9 & 5.1 \\
\hline \multicolumn{14}{|c|}{ San Marcos } \\
\hline P822 & $7^{\circ} 21.49^{\prime}$ & $78^{\circ} 08.06^{\prime}$ & $264.1 / 26$ & $10 / 10$ & $0 / 10$ & 175.4 & -8.3 & 110.4 & 4.6 & 175.4 & 17.6 & 110.4 & 4.6 \\
\hline P823 & $7^{\circ} 21.49^{\prime}$ & $78^{\circ} 08.06^{\prime}$ & $318.8 / 18^{\mathrm{b}}$ & $9 / 9$ & $0 / 9$ & 192.2 & -1.2 & 63.6 & 6.5 & 191.0 & 11.5 & 60.6 & 6.7 \\
\hline P824 & $7^{\circ} 21.49^{\prime}$ & $78^{\circ} 08.06^{\prime}$ & $214.4 / 30$ & $9 / 10$ & $9 / 0$ & 185.3 & 5.3 & 123.5 & 4.7 & 191.2 & 18.8 & 123.5 & 4.7 \\
\hline P826 & $7^{\circ} 20.47^{\prime}$ & $78^{\circ} 09.08^{\prime}$ & $19.8 / 13.3$ & $6 / 9$ & $0 / 6$ & 190.0 & 25.9 & 29.9 & 12.5 & 184.1 & 22.9 & 29.9 & 12.5 \\
\hline $\mathrm{P} 827^{\mathrm{c}}$ & $7^{\circ} 20.17^{\prime}$ & $78^{\circ} 09.52^{\prime}$ & $62.8 / 76.5$ & $4 / 9$ & $0 / 4$ & 184.0 & 68.0 & 867.2 & 3.1 & 164.0 & -5.4 & 867.2 & 3.1 \\
\hline P828 & $7^{\circ} 20.04^{\prime}$ & $78^{\circ} 08.55^{\prime}$ & $213.8 / 7$ & $8 / 11$ & $0 / 8$ & 191.4 & 24.2 & 142.9 & 4.6 & 194.5 & 26.7 & 142.9 & 4.6 \\
\hline P830 & $7^{\circ} 20.42^{\prime}$ & $78^{\circ} 08.87^{\prime}$ & $359.8 / 18$ & $7 / 8$ & $2 / 0$ & 178.4 & 13.5 & 120.4 & 6.1 & 174.3 & 12.4 & 120.4 & 6.1 \\
\hline P831 & $7^{\circ} 20.47^{\prime}$ & $78^{\circ} 08.82^{\prime}$ & $333.4 / 4$ & $8 / 8$ & $0 / 8$ & 193.8 & 21.1 & 56.6 & 7.4 & 192.5 & 23.6 & 56.6 & 7.4 \\
\hline Mean & & & & $7 / 8$ & & 186.5 & 11.6 & 29.3 & 11.3 & 186.0 & 19.3 & 68.8 & 7.3 \\
\hline Mean & & & & $8 / 8$ & & 186.4 & 18.1 & 11.6 & 17.0 & 183.2 & 16.3 & 30.7 & 10.2 \\
\hline \multicolumn{14}{|c|}{ Canyon de Huaylas } \\
\hline P801 OL au & \multicolumn{2}{|c|}{$\sim 30 \mathrm{~m}$ above $\mathrm{P} 802$} & $321.2 / 2$ & $7 / 7$ & $7 / 0$ & 174.0 & 12.9 & 32.5 & 10.7 & 173.6 & 13.9 & 32.5 & 10.7 \\
\hline P802 QL au & $9^{\circ} 37.88^{\prime}$ & $77^{\circ} 28.12^{\prime}$ & $332.4 / 7.5$ & $12 / 12$ & $0 / 12$ & 178.8 & 9.5 & 53.1 & 6.0 & 177.5 & 12.8 & 53.1 & 6.0 \\
\hline P803 QL au & $9^{\circ} 37.93^{\prime}$ & $77^{\circ} 28.35^{\prime}$ & $326.7 / 7^{\mathrm{b}}$ & $8 / 8$ & $0 / 8$ & 172.8 & 16.7 & 868.0 & 1.9 & 170.7 & 19.8 & 868.0 & 1.9 \\
\hline P804 QL au & $\sim 30 \mathrm{~m} \mathrm{ab}$ & ove P805 & $319.9 / 3$ & $9 / 9$ & $0 / 9$ & 174.7 & 10.9 & 326.2 & 2.9 & 174.2 & 12.6 & 326.2 & 2.9 \\
\hline P805 QL au & $\sim 70 \mathrm{~m} \mathrm{ab}$ & ove P806 & $325.5 / 9$ & $7 / 7$ & $0 / 7$ & 175.1 & 16.4 & 43.0 & 9.3 & 172.4 & 20.7 & 43.0 & 9.3 \\
\hline P806 QL au & $\sim 400 \mathrm{~m} \mathrm{a}$ & oove P807 & $334.2 / 7$ & $8 / 8$ & $8 / 0$ & 173.6 & 7.9 & 109.9 & 5.3 & 172.5 & 10.1 & 109.9 & 5.3 \\
\hline P807 QL bu & $9^{\circ} 38.25^{\prime}$ & $77^{\circ} 28.74^{\prime}$ & $321.2 / 20$ & 9/9 & $0 / 9$ & 180.5 & 10.7 & 24.6 & 10.6 & 175.7 & 22.8 & 24.6 & 10.6 \\
\hline P808 QL bu & $9^{\circ} 38.36^{\prime}$ & $77^{\circ} 28.84^{\prime}$ & $326.2 / 22$ & $6 / 7$ & $6 / 0$ & 156.9 & 15.9 & 24.7 & 13.7 & 150.0 & 18.7 & 24.7 & 13.7 \\
\hline P809 TL bu & $9^{\circ} 42.00^{\prime}$ & $77^{\circ} 27.50^{\prime}$ & $339.2 / 16$ & $5 / 10$ & $0 / 2$ & 163.3 & 17.4 & 52.3 & 12.1 & 158.2 & 17.8 & 52.3 & 12.1 \\
\hline P810 TL bu & $\sim 150 \mathrm{~m} \mathrm{~b}$ & elow P809 & $336.2 / 15$ & $9 / 9$ & $9 / 0$ & 162.5 & 21.2 & 34.4 & 8.9 & 156.5 & 22.0 & 34.4 & 8.9 \\
\hline P811 TL bu & $\sim 15 \mathrm{~m}$ be & low P810 & $326.2 / 12$ & $4 / 4$ & $4 / 0$ & 173.7 & 11.2 & 80.2 & 10.3 & 171.0 & 16.5 & 80.2 & 10.3 \\
\hline P812 TL bu & $\sim 45 \mathrm{~m} \mathrm{be}$ & low P811 & $331.2 / 16$ & $8 / 10$ & $8 / 0$ & 171.9 & 26.3 & 12.1 & 16.6 & 163.5 & 30.9 & 12.1 & 16.6 \\
\hline Mean (above) & & & & $6 / 6$ & & 174.8 & 12.4 & 372.3 & 3.5 & 173.5 & 15.0 & 284.8 & 4.0 \\
\hline Mean (below) & & & & $6 / 6$ & & 168.2 & 17.2 & 62.1 & 8.6 & 162.4 & 21.7 & 62.1 & 8.6 \\
\hline Mean & & & & $12 / 12$ & & 171.6 & 14.8 & 89.2 & 4.6 & 168.1 & 18.4 & 65.2 & 5.4 \\
\hline
\end{tabular}

\footnotetext{
${ }^{\mathrm{a}}$ Note $\lambda \mathrm{s}$, site latitude; $\phi s$, site longitude; no/No, number of samples retained in the mean/total number of samples demagnetized; N, R, of the retained samples, number possessing normal $(\mathrm{N})$ or reversed $(\mathrm{R})$ polarity (note that no polarity was assigned to samples whose directions were determined with great circles); D, declination; I, inclination; $\alpha_{95}$, radius of the cone in which the mean direction lies within $95 \%$ confidence; $\mathrm{k}$, best estimate of the precision parameter; QL, TL, Quebrada Llocalla and Telar Huain sections, respectively; au (bu), above (below) the angular unconformity identified in the Lloclla Formation.

${ }^{\mathrm{b}}$ Average strike and dip.

${ }^{\mathrm{c}}$ Site rejected (see text).
} 


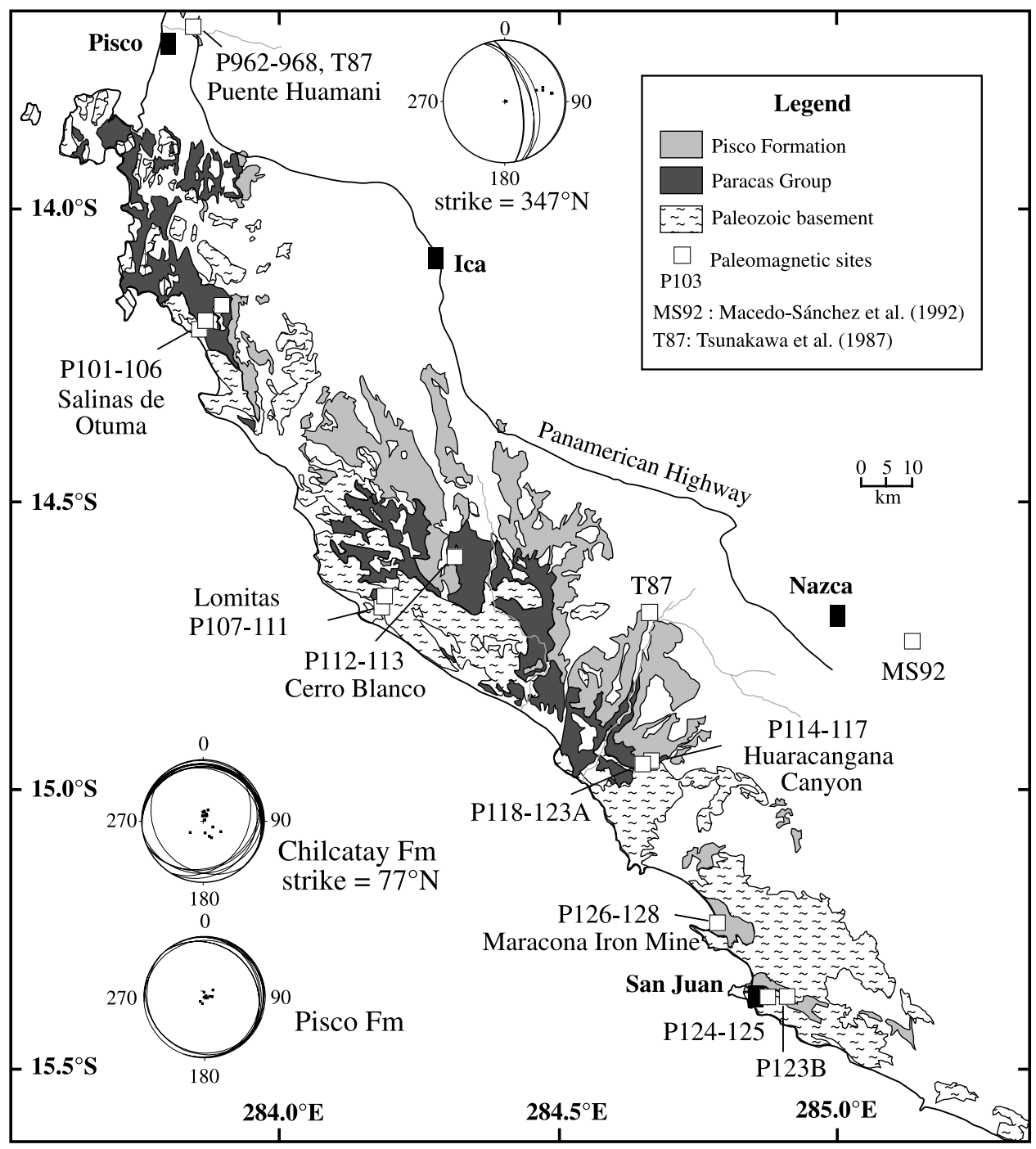

Figure 4. Simplified geologic map of the Pisco basin [after Vidal, 1978; Davila, 1993; Montoya et al., 1994]. The open squares are the paleomagnetic sites from this study (Table 2), Tsunakawa et al. [1987] (T87), and Macedo-Sánchez et al. [1992] (M92). Stereonet plots of bedding and poles to bedding (upper hemisphere) are shown (data from Table 2). Note that the fold axis from Puente Huamani parallels the Andean trend; interestingly, the northernmost extent of the Precambrian basement ends just south of these localities. The other bedding data are consistent with the interpretation that the maximum extension direction lies perpendicular to the Andean trend, perhaps suggesting that the Precambrian basement has rigidly transmitted compression behind the forearc in a manner similar to that proposed by Roperch et al. [2000]. Pisco Formation bedding data from same region are less tilted.

from WNW to NNW (Figure 1). The basement rocks are composed mostly of Precambrian gneiss and lower Paleozoic granite [Shackleton et al., 1979]. These are covered by Upper Jurassic to Lower Cretaceous volcanics and sediments [Montoya et al., 1994], which are in turn unconformably overlain by Cenozoic marine sediments deposited during at least three transgressive cycles from circa 40 to 2 Ma [e.g., Macharé et al., 1988; Marocco and de Muizon, 1988; Dunbar et al., 1990; Devries, 1998].

[15] In total, we sampled 311 cores at 36 sites in the Cenozoic sediments. We followed the terminology of
Dunbar et al. [1990], who divided the stratigraphy into the Paracas Group and the Chilcatay and Pisco formations, each separated by a hiatus and a slight angular unconformity. Note that the Montoya et al. [1994] maps, which we used to construct Figure 4, divide the Tertiary sediments into the Paracas and Pisco formations only, with the Chilcatay Formation included with Paracas. The lithology of these units is similar, with coarse-grained facies at the base that prograde upward into sandstone and siltstone. Upper parts of each transgressive unit are dominated by biogenic facies, usually consisting of diatomaceous silt- 
stone and mudstone [Dunbar et al., 1990]. Abundant mollusc, diatom and foraminifera fossils constrain the Paracas group as upper Eocene to Oligocene.

[16] In this study we concentrated on the Chilcatay (OligoMiocene) (132 samples, 15 sites) and Pisco (circa upper Miocene to Pliocene) (179 samples, 21 sites) formations at localities that were paleontologically well described (Figure 4). In particular, we sampled the Salinas de Otuma section of Macharé et al. [1988, sect. 1] who found diatoms Bogorovia veniamini, Cestodiscus sp. and Thalassionema notzschioides near the base, indicative of the late Oligocene to early Miocene (sites P101 to P104). At this section, Chilcatay sediments are separated from the Pisco Formation by a slight angular unconformity [Macharé et al., 1988]. We collected two sites (P105 and P106) above the unconformity (Pisco Formation). Farther south we sampled sites P107 to P111 at the Lomitas section where molluscs Pitar mancorensis, Cyclocardita n. sp. and a suite of diatoms indicate a late Oligocene to early Miocene age [Macharé et al., 1988]. Closer to the Panamerican Highway, we collected sites P112 and P113 at Cerro Blanco, which are assigned to the Pisco Formation [Dunbar et al., 1990, Figure 10, sect. B]. The next locality at the Huaracangana Canyon is well studied, containing Pisco facies at Molde de Queso (sites P114-P117) within which a tuffaceous sandstone horizon yielded a K-Ar date of $5.5 \pm 0.1 \mathrm{Ma}$ [Dunbar et al., 1990]. Farther down the canyon, we sampled sites P118-P123A in the Chilcatay Formation [Dunbar et al., 1990, Figure 8, sect. D], which is thought to lie in the earliest middle Miocene (16.4 to $15 \mathrm{Ma}$ ) based on Praeorbulina glomerosa and Cestodiscus peplum. We sampled one site (P123B) on the road from the Panamerican Highway to the navel base at San Juan, and two sites in the environs of the base (P124 and P125). The ages of these sites are ambiguous as Macharé et al. [1988] assigned them to the Chilcatay Formation and Dunbar et al. [1990] to the Pisco Formation. Here we assign them to the Pisco Formation, consistent with Vidal [1978, unpublished data, 2001]. Farther north, we were given permission to access the Marcona iron mine. There, on the coast, is a well-exposed section of Pisco Formation sediments that disconformably overlie the Siluro-Devonian San Nicolás batholith [Shackleton et al., 1979; Montoya et al., 1994]. The top of the section is a massive slump block. We sampled three sites (P126-P128) below the slump. Finally, we collected seven sites at Puente Huamani, near the northern-most exposure of the Pisco Basin. Six sites (P962-P967) were sampled in a $\sim 250 \mathrm{~m}$ thick section that dips $\sim 46^{\circ}$ to $68^{\circ}$ to the east, as well as one flat-lying site (P968) east of the highway [see Mercier et al., 1992, Figure 22]. Macharé [1987] found several diatom species in one sample (collected by de Muizon) from this section, which places it in the upper Miocene to Pliocene (Pisco Formation). These units were folded during the early Pleistocene or possibly the latest Pliocene [Mercier et al., 1992].

\section{Paleomagnetism}

[17] Samples were collected using a portable drill and oriented with magnetic and sun compasses from the finest- grained layers available. A typical sampling site consists of eight cores drilled from six independent horizons that span six meters in thickness in order to average-out secular variation. Remanent magnetizations were measured with a three-axis 2G DC-SQUID magnetometer installed in a magnetically shielded room at the Institut de Physique du Globe de Paris. Pilot studies using stepwise thermal and alternating field (AF) demagnetization (14 to 22 steps) were conducted with Shonstedt coils and in a furnace whose residual field was $<20 \mathrm{nT}$. Bulk susceptibility was measured after each heating step for half of the samples to monitor potential changes in magnetic mineralogy. Magnetic directions were determined by principal component analysis [Kirschvink, 1980], except when multiple components with overlapping unblocking or coercivity spectra were present, in which case we used the remagnetization great circle method [McFadden and McElhinny, 1988]. Site mean directions were calculated using Fisher [1953] statistics. We used the Watson and Enkin [1993] fold test using 1000 simulations and $5^{\circ}$ uncertainties on bedding attitudes. The test statistic is given at the optimum degree of untilting with uncertainties reported at the $95 \%$ confidence level; the reversal test follows McFadden and McElhinny [1990].

\subsection{Subandean Zone}

[18] From the pilot study results, we used mainly hybrid (AF + thermal) demagnetization for the Ipururo Formation red sandstones and thermal demagnetization for the Chambira Formation yellow sandstones (Figure 5). For both formations, stepwise demagnetization mostly isolated two magnetic components: a low temperature/coercivity component that lies close to the present magnetic field direction and a high temperature/coercivity component (HTC) that appears after AF demagnetization to $38 \mathrm{mT}$ or generally above temperatures from $350^{\circ}$ to $550^{\circ} \mathrm{C}$. The Ipururo Formation had relatively low natural remanent magnetization (NRM) intensities $(\sim 1 \mathrm{~mA} / \mathrm{m})$ with relatively noisy HTC directions as reflected in corresponding site mean $\alpha_{95} \mathrm{~S}$ on the order of $10^{\circ}$ to $15^{\circ}$ (Table 1). Both normal and reverse polarities were isolated in roughly equal proportions. The NRM intensities of the Chambira Formation samples were generally $>10 \mathrm{~mA} / \mathrm{m}$ and demagnetization trajectories were fairly well defined (Figure 5). Site mean $\alpha_{95} \mathrm{~S}$ are $<10^{\circ}$ and all directions have reverse polarity (Table 1). Curie point experiments and unblocking temperatures suggest that titanomagnetite and/or hematite carry the magnetic remanence of the Tarapoto samples. When calculating an overall mean direction for the Ipururo Formation, we excluded site $\mathrm{P} 960$ because its $\alpha_{95}$ exceeded $20^{\circ}$, despite the fact that its tilt-corrected mean direction was coherent with the others (Figure 5). The fold test statistic for the HTC maximizes at $104 \pm 16 \%$ unfolding and the reversal test is positive suggesting the magnetization is a prefolding, primary remanence. For the Chambira Formation, the test statistic based on only three sites maximizes at $38 \pm 27 \%$ unfolding. The suggestion of a synfolding magnetization is influenced by site P950, which may be due to incomplete isolation of the primary component, poor bedding attitude correction or remagnetization. The latter option is unlikely 

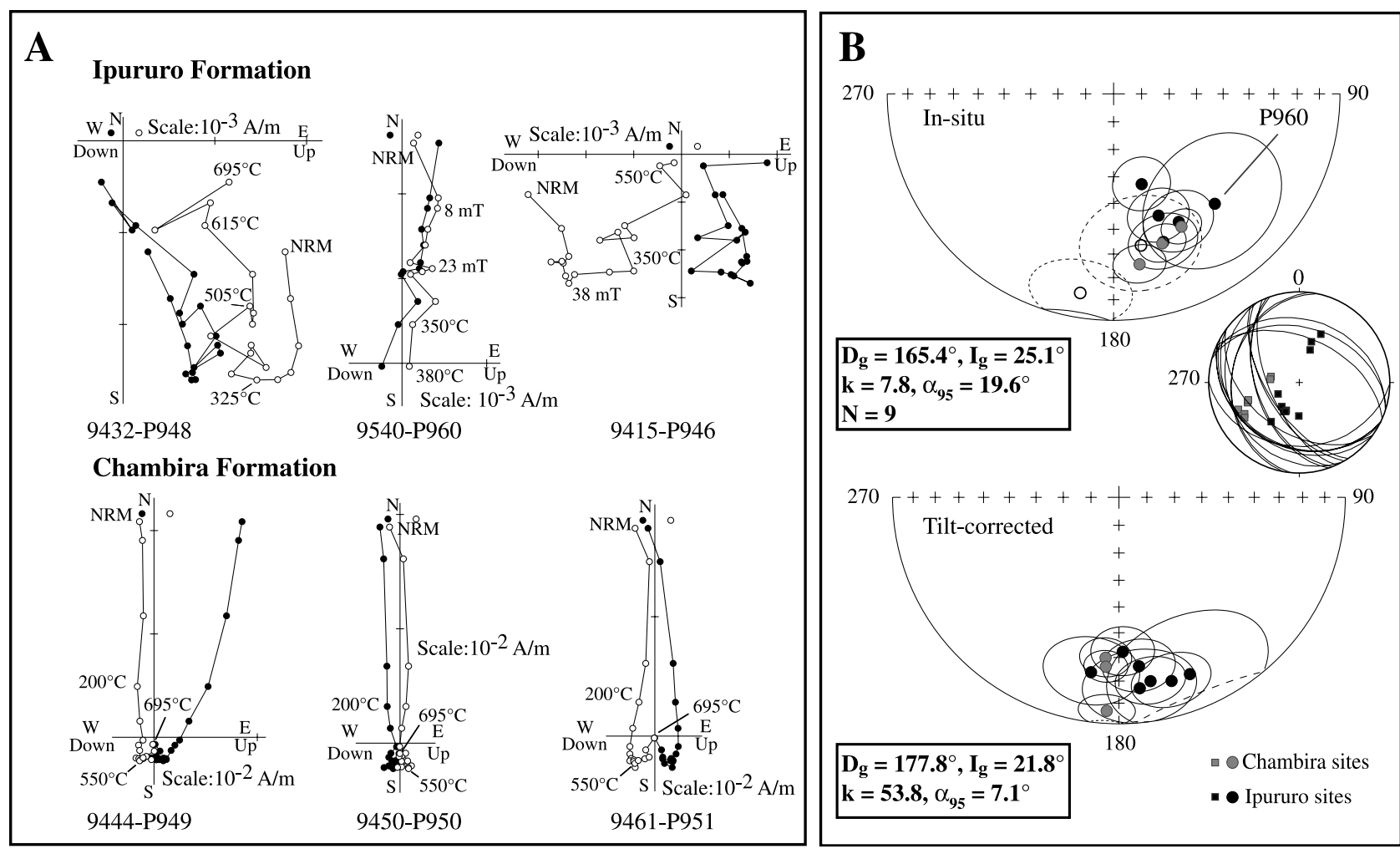

Figure 5. (a) In situ orthogonal stepwise demagnetization diagrams for the Ipururo and Chambira formations. (b) Equal-area projections of site mean directions (all in reversed polarity format) and stereonet plots of bedding and poles to bedding (upper hemisphere).

given the reversed polarity directions thus we suspect one or a combination of the former two possibilities. Because of the limited number of sites, and because the tilt corrected overall mean direction of the Chambira Formation is indistinguishable at $95 \%$ confidence limits from the Ipururo Formation overall mean direction [McFadden and Lowes, 1981], we grouped them together to calculate an overall mean for the late Oligocene through Miocene time window (Table 1). The test statistic for the nine sites maximizes at $94 \pm 14 \%$ unfolding and the reversal test is positive, suggesting the remanence is primary.

\subsection{Intracordilleran Basins}

\subsubsection{Cajabamba Basin}

[19] In seven of the eight sites collected from the Cajabamba Formation fine sandstones, thermal demagnetization isolated well-defined magnetic components until final unblocking at temperatures $<580^{\circ} \mathrm{C}$ (Figure 6a). These samples are represented by both polarities at higher temperatures $\left(>250^{\circ} \mathrm{C}\right)$ after removal of a mostly north and down directed component. NRM intensities range from $\sim 0.1 \mathrm{~mA} /$ $\mathrm{m}$ to occasionally $10 \mathrm{~mA} / \mathrm{m}$; magnetomineralogical analyses suggest the remanence is carried by titanomagnetite. Site P821 possessed unstable magnetizations and was omitted from further analysis. The fold test statistic maximized at $89 \pm 45 \%$. The large confidence interval arises from fairly homogeneous bedding attitudes of the sampling sites. How- ever the test parameter is compatible with a prefolding magnetization and excludes a postfolding hypothesis; moreover, the reversal test is positive which favors the interpretation of a primary, prefolding remanence. Both the in situ and tilt-corrected overall mean directions lie far from expected Bruhnes or Matuyama field directions thus the remanent directions cannot be representative of a recent field (Figure 6a).

\subsubsection{San Marcos Basin}

[20] Magnetic characteristics of the eight San Marcos basin sites were similar to those from the Cajabamba basin - thermal demagnetization revealed two stable magnetic components with solely normal polarity at low temperatures and dual polarities at higher temperatures (Figure 6b). Magnetomineralogical studies again reveal that titanomagnetite carries the magnetic remanence. Figure $6 \mathrm{~b}$ shows the individual site mean directions before and after unfolding. The fold test statistic based on the eight sites maximizes at $72 \pm 7 \%$ unfolding, signaling a synfolding magnetization. Closer inspection shows that a synfolding interpretation is controlled by site P827. Because of lithological constraints, the nine samples collected at site P827 come from only two beds. The five samples from one of the beds were remagnetized in a recent field as the in situ direction $\left(\mathrm{D}=2.9^{\circ}, \mathrm{I}=\right.$ $\left.-8.7^{\circ}\right)$ lies close to the axial dipole field direction $\left(\mathrm{D}=0^{\circ}\right.$, $\left.\mathrm{I}=-14.6^{\circ}\right)$, whereas the tilt-corrected direction $\left(\mathrm{D}=27.9^{\circ}\right.$, $\left.\mathrm{I}=52.7^{\circ}\right)$ is incoherent with any reasonable tectonic interpretation. The magnetizations for the four samples from 


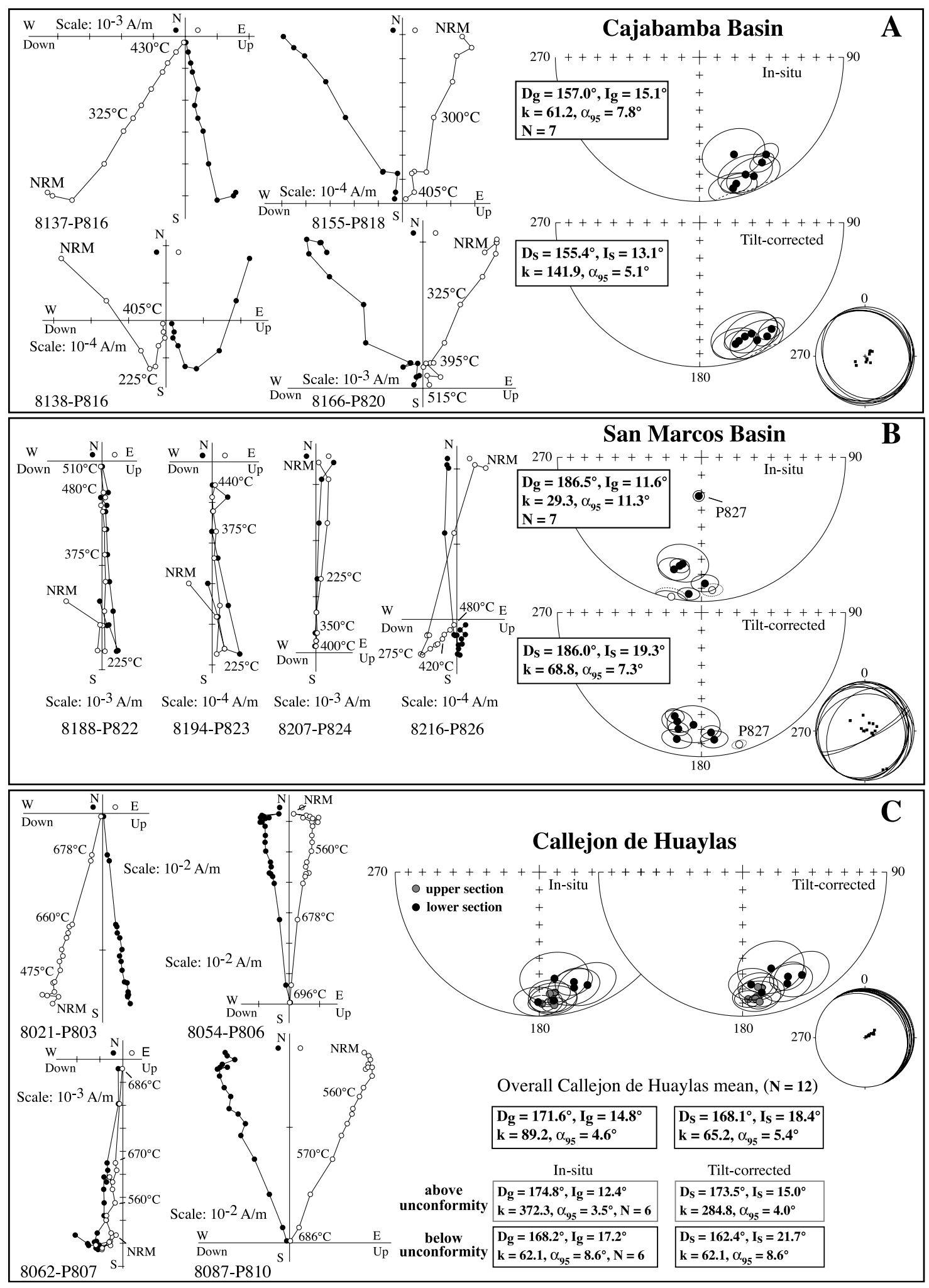

Figure 6. In situ orthogonal stepwise demagnetization diagrams (left) and equal-area projections of site mean directions (all in reversed polarity format) (right) for the (a) Cajabamba, (b) San Marcos and (c) Callejón de Huaylas. Stereonet plots of bedding and poles to bedding (upper hemisphere) are also shown. Overall site mean directions for the Callejón de Huaylas (Figure 6c) are listed as well as the overall site mean directions above and below the angular unconformity (see text). Individual site mean directions for the sites above (below) the angular unconformity are shaded (black). 
the other bed yielded well-defined and consistent trajectories $\left(\right.$ small $\left.\alpha_{95}\right)$ at high temperatures. Neither the in situ nor tilt-corrected mean inclinations of P827 based on these 4 samples are representative of a middle Miocene to Recent field (Table 1). As the magnetization direction isolated for site P827 comes from a single bed, it could be that secular variation was not averaged out. This site is clearly an enigma in that it dips steeply $\left(77^{\circ}\right)$, whereas other strata from intra-Cordilleran Neogene basins from northern Peru have gentle dips $\left(30^{\circ}\right.$, Figure 6 ; Table 1$)$, consistent with the conclusions of geodynamic interpretations that these rocks were tilted in extension and not folded in compression. Omitting site P827 and reapplying the fold test shows optimum untilting at $96 \pm 24 \%$; the reversal test is positive. This leaves two possibilities: either (1) all sites were remagnetized during tilting which occurred simultaneously with sedimentation [Bellier et al., 1989] or (2) site P827 is anomalous (maybe remagnetized during folding/tilting) while the other sites possess prefolding, primary magnetizations. Because of the uncertainties surrounding site P827 we prefer the latter interpretation. In either case, the overall mean direction of $\mathrm{N}=7$ sites at $100 \%$ unfolding $(\mathrm{D}=$ $186.0^{\circ}, \mathrm{I}=19.3^{\circ}, \mathrm{k}=68.8, \alpha_{95}=7.3^{\circ}$ ) versus $\mathrm{N}=8$ sites at $72 \%$ unfolding $\left(\mathrm{D}=183.4^{\circ}, \mathrm{I}=17.3^{\circ}, \mathrm{k}=45.7, \alpha_{95}=8.3^{\circ}\right)$ are the same within $95 \%$ confidence limits [McFadden and Lowes, 1981].

\subsubsection{Callejón de Huaylas}

[21] A total of 12 sites (100 cores) of predominantly finegrained sandstones were drilled in the Callejón de Huaylas basin: 8 sites from Quebrada Lloclla (P801 to P808) and the other 4 sites from Telar Huain (P809 to P812) (Figure 3). Anisotropy of magnetic susceptibility (AMS) was measured for three samples per site with an AGICO KLY-2 Kappabridge. The median bulk susceptibility is $3 \times 10^{-4}$ (SI) with a large spread from $2 \times 10^{-5}$ to $2 \times 10^{-2}(\mathrm{SI})$. Anisotropy percentages $\left(\mathrm{P}^{\prime}\right)$ range from $0.1 \%$ to $4.5 \%$ with a median value of $0.8 \%$. When $\mathrm{P}^{\prime}$ is $<1 \%$, the shape parameter $(\mathrm{T})$ is random, being either oblate or prolate; when $\mathrm{P}^{\prime}$ is $>1 \%$, the shape parameter $(\mathrm{T})$ is decidedly oblate. Minimum anisotropy axes lie perpendicular to the stratification plane, and maximum and intermediate axes are randomly distributed within the horizontal plane after tilt correction. Overall, the AMS characteristics are typical of a sedimentary fabric, unaffected by a subsequent tectonic foliation. Thermal demagnetization of all twelve sites yielded well-defined unblocking trajectories that decayed toward the origin after initial cleaning at low temperatures or low alternating fields (Figure 6c). Dual polarities were present in both sections. Maximum unblocking temperatures of $680^{\circ} \mathrm{C}$ are indicative of hematite yet thermomagnetic analyses also indicate the presence of titanomagnetite. NRM intensities range between 0.5 and $93 \mathrm{~mA} / \mathrm{m}$ with a mean around $10 \mathrm{~mA} / \mathrm{m}$.

[22] Site mean directions were calculated for each of the 12 sites (Figure 6c and Table 1). Despite yielding a positive reversals test, the test statistic maximizes at $-19 \%$ unfolding with an error envelope at $-46 \% /+35 \%$, suggesting a posttilting remanence. However, because these rocks possess both normal and reversed polarities, the time to overprint them must have been long enough to span at least one, and likely five reversals, as the Quebrada Lloclla section sites were collected in stratigraphic order with P808 at the base and P801 at the top, and display a N-RN-R-N reversal pattern. Judging the demagnetization diagrams, it is clear that they possess very stable magnetizations so viscous effects should be ruled out. Looking more carefully at the data set we found an alternate solution to the remagnetization hypothesis. We recall that an angular unconformity exists in the Lloclla Formation, with dips $>10^{\circ}$ below and only slight $\operatorname{dips}\left(<10^{\circ}\right)$ above. When reexamining the site mean directions we found that declinations change at this transition with declinations below being $162^{\circ}$ and those above at $175^{\circ}$. The mean directions of the 6 sites above and 6 sites below the transition are different at 95\% confidence limits [McFadden and Lowes, 1981] (Figure 6c), which explains why the fold test is negative for the entire population. When treating as two separate populations, the homogeneity of the strike corrections prevents a meaningful application of the fold test, however positive reversal tests were obtained in both cases. Thus we are left with two possible interpretations of the paleomagnetic data from the Callejón de Huaylas: (1) complete, yet pre-Bruhnes remagnetization, or (2) the angular unconformity represents a distinct structural and tectonic boundary with beds below being rotated $\sim 11^{\circ}$ counterclockwise more than those above. We prefer the latter because it is more consistent with the paleomagnetic and geologic data.

\subsection{Pisco Basin}

[23] NRM intensities for the Chilcatay Formation were fairly uniform, averaging $1 \times 10^{-3} \mathrm{~A} / \mathrm{m}$. Those for the Pisco Formation were much more variable, being $0.4 \times$ $10^{-3} \mathrm{~A} / \mathrm{m}$ in the diatomaceous facies at Puente Huamani, $70 \times 10^{-3} \mathrm{~A} / \mathrm{m}$ at the San Nicolás batholith, and $3 \times$ $10^{-3} \mathrm{~A} / \mathrm{m}$ for the rest. For both formations, thermal demagnetization generally unblocked a single linear magnetic component that decayed toward the origin above $\sim 200^{\circ} \mathrm{C}$ after removing a spurious direction (yet usually with northward declinations and shallow inclinations), with $90 \%$ of the remanence removed by $500^{\circ} \mathrm{C}$, indicating the presence of titanomagnetite (Figure 7). Only the magnetic remanences of sites P126-P128 from the San Nicolás batholith area (whose NRM intensities are over a magnitude greater than the rest) persist to $580^{\circ} \mathrm{C}$, indicative of Ti-poor magnetite (Figure 7a). Often the magnetic directions became erratic when heating above $300^{\circ} \mathrm{C}$, which did or did not coincide with changes in magnetic susceptibility. Most samples possessed a magnetic mineral that had a low Curie temperature $\left(\sim 120^{\circ} \mathrm{C}\right)$ and was resistant to $\mathrm{AF}$ demagnetization (high coercivity), characteristic of an iron hydroxide (limonite, goethite). Sometimes this latter mineral dominated more than $80 \%$ of the NRM intensity (Figure 7 ). Because of their sensitivity to thermal demagnetization, we found that the best way to treat most samples was to first thermally demagnetize them in one step at $135^{\circ} \mathrm{C}$, then apply alternating field demagnetization. In this way, linear demagnetization components were more readily obtained. 


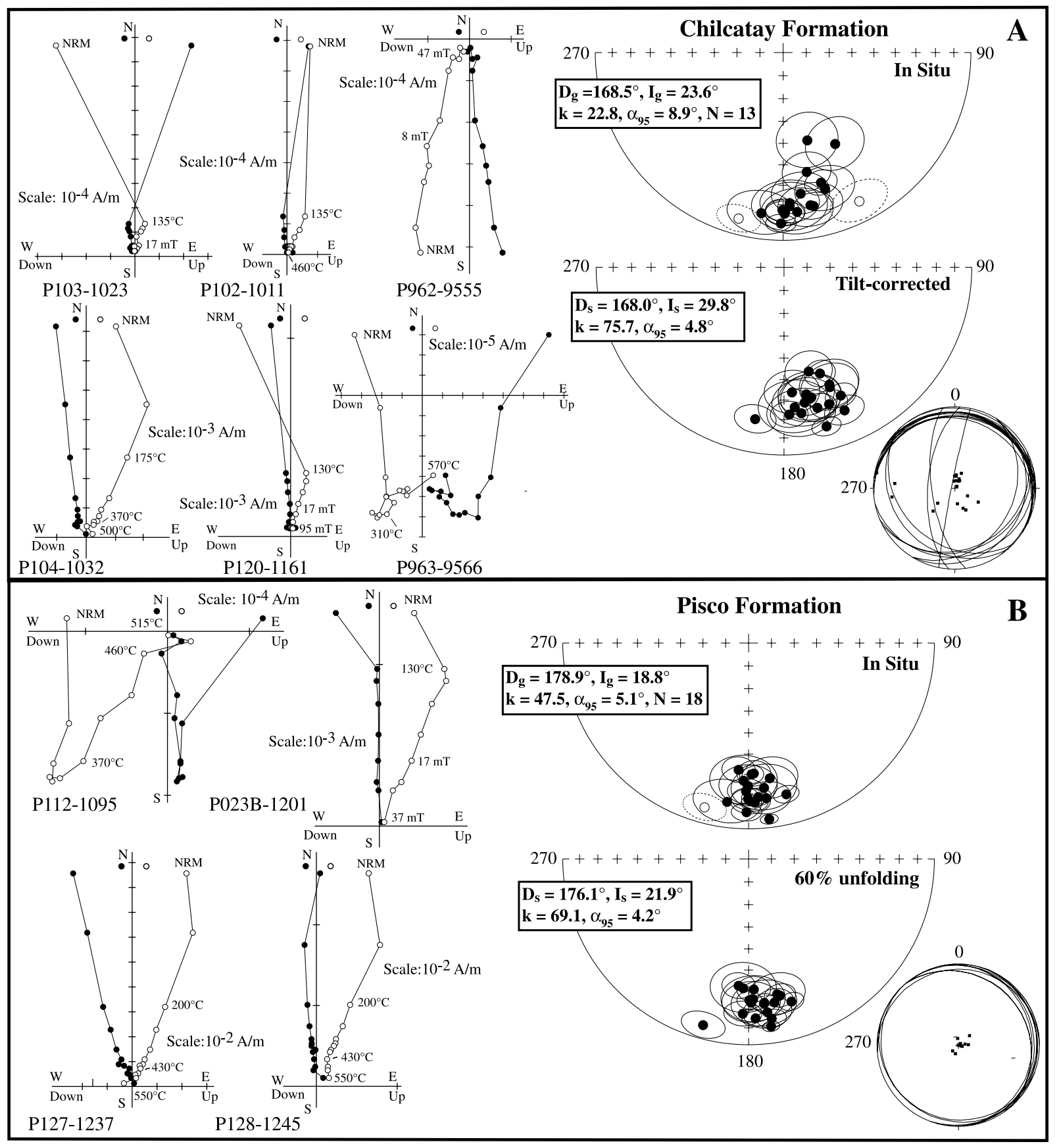

Figure 7. In situ orthogonal stepwise demagnetization diagrams (left) and equal-area projections of site mean directions (all in reversed polarity format) (right), for the (a) Chilcatay and (b) Pisco formations. Individual site mean directions for the Chilcatay Formation are shown at $0 \%$ and $100 \%$ unfolding. For the Pisco Formation they are shown at $0 \%$ and $60 \%$ unfolding (where $\mathrm{k}$ is maximum, see text). Stereonet plots of bedding and poles to bedding (upper hemisphere) are also included.

[24] The number of samples possessing reversed polarity were few, representing only $20 \%$ of the directions fit using principal component analysis (Table 2); no polarity was assigned to samples fit with great circles, which represent only $15 \%$ of the total population. For some localities, only a few stable high temperatures magnetizations were isolated per site, so we grouped them together to calculate a composite site mean direction (P115-P116-P117 and P109-P110-P111, Table 2). The most difficult aspect when assigning magnetic components to these formations arises from the flat lying nature of the bedding, which hinders one from distinguishing primary magnetizations from those overprinted in a recent or Bruhnes field, except when polarity is reversed. From the fact that only $20 \%$ of the 
Table 2. High Temperature-High Coercivity Paleomagnetic Results From the Pisco Basin ${ }^{\mathrm{a}}$

\begin{tabular}{|c|c|c|c|c|c|c|c|c|c|c|c|c|c|}
\hline \multirow[b]{2}{*}{ Site Number } & \multirow[b]{2}{*}{$\lambda s,{ }^{\circ} \mathrm{S}$} & \multirow[b]{2}{*}{$\phi \mathrm{s},{ }^{\circ} \mathrm{W}$} & \multirow{2}{*}{$\begin{array}{c}\text { Average } \\
\text { Strike, Dip }\end{array}$} & \multirow[b]{2}{*}{ no/No } & \multirow[b]{2}{*}{$\mathrm{N} / \mathrm{R}$} & \multicolumn{4}{|c|}{ Geographic } & \multicolumn{4}{|c|}{ Stratigraphic } \\
\hline & & & & & & $\mathrm{Dg}$ & Ig & $\mathrm{k}$ & $\alpha_{95}$ & Ds & Is & $\mathrm{k}$ & $\alpha_{95}$ \\
\hline \multicolumn{14}{|c|}{ Pisco Formation } \\
\hline P962 & $13^{\circ} 41.18^{\prime}$ & $78^{\circ} 10.08^{\prime}$ & $340.8 / 46$ & $7 / 8$ & $1 / 3$ & 187.7 & 14.8 & 29.1 & 11.9 & 168.8 & 29.5 & 29.1 & 11.9 \\
\hline P963 & \multicolumn{2}{|c|}{$\sim 15$ m below P962 } & $340.8 / 46$ & $10 / 10$ & $0 / 7$ & 179.3 & 15.9 & 50.7 & 7.0 & 161.8 & 24.2 & 50.7 & 7.0 \\
\hline P964 & \multicolumn{2}{|c|}{$\sim 150 \mathrm{~m}$ above P962 } & $343.8 / 54.5$ & $8 / 9$ & $5 / 0$ & 15.0 & 9.3 & 60.3 & 7.4 & 10.7 & -18.8 & 60.3 & 7.4 \\
\hline P965 & \multicolumn{2}{|c|}{$\sim 150 \mathrm{~m}$ above P964 } & $339.8 / 56.0$ & $8 / 9$ & $8 / 0$ & 0.2 & -17.2 & 89.7 & 5.9 & 336.1 & -26.2 & 89.7 & 5.9 \\
\hline P967 & \multicolumn{2}{|c|}{$\sim 150 \mathrm{~m}$ above P965 } & $350.3 / 67.5$ & $9 / 10$ & $9 / 0$ & 0.7 & -9.8 & 104.1 & 5.1 & 345.0 & -13.3 & 104.1 & 5.1 \\
\hline P968 & $13^{\circ} 41.21^{\prime}$ & $78^{\circ} 09.50^{\prime}$ & $351.8 / 2.0$ & $10 / 13$ & $1 / 3$ & 177.8 & 15.1 & 118.5 & 4.7 & 177.2 & 15.3 & 118.5 & 4.7 \\
\hline P105 & $14^{\circ} 11.00^{\prime}$ & $76^{\circ} 07.68^{\prime}$ & $325.2 / 3$ & $6 / 6$ & $6 / 0$ & 353.5 & -17.1 & 60.1 & 8.7 & 352.7 & -18.5 & 60.1 & 8.7 \\
\hline P106 & $14^{\circ} 11.00^{\prime}$ & $76^{\circ} 07.68^{\prime}$ & $265.1 / 7$ & $8 / 8$ & $8 / 0$ & 2.1 & -26.8 & 20.4 & 12.6 & 2.6 & -33.7 & 20.4 & 12.6 \\
\hline $\mathrm{P} 112$ & $14^{\circ} 35.14^{\prime}$ & $75^{\circ} 41.05^{\prime}$ & Horizontal & $9 / 9$ & $0 / 4$ & 177.7 & 30.4 & 71.7 & 6.4 & 177.7 & 30.4 & 71.7 & 6.4 \\
\hline P113 & \multicolumn{2}{|c|}{$\sim 15 \mathrm{~m}$ above $\mathrm{P} 112$} & Horizontal & $8 / 10$ & $8 / 0$ & 353.9 & -22.7 & 22.4 & 12.0 & 353.9 & -22.7 & 22.4 & 12.0 \\
\hline P114 & $14^{\circ} 57.85^{\prime}$ & $75^{\circ} 17.20^{\prime}$ & $8.5 / 4.7$ & $9 / 9$ & $0 / 5$ & 180.2 & 24.1 & 25.3 & 10.7 & 178.2 & 23.3 & 25.3 & 10.7 \\
\hline P115-16-17 & $14^{\circ} 57.85^{\prime}$ & $75^{\circ} 17.20^{\prime}$ & $8.5 / 4.7$ & $12 / 23$ & $0 / 4$ & 184.5 & 32.1 & 50.4 & 6.4 & 181.6 & 31.7 & 50.4 & 6.4 \\
\hline P123B & $15^{\circ} 21.55^{\prime}$ & $75^{\circ} 06.52^{\prime}$ & $109.6 / 9$ & $10 / 10$ & $10 / 0$ & 358.7 & -30.0 & 110.0 & 4.6 & 0.2 & -21.6 & 110.0 & 4.6 \\
\hline P124 & $15^{\circ} 21.58^{\prime}$ & $75^{\circ} 09.35^{\prime}$ & $356.3 / 10$ & $8 / 9$ & $8 / 0$ & 351.1 & -27.2 & 28.2 & 10.6 & 346.1 & -25.8 & 28.2 & 10.6 \\
\hline P125 & $15^{\circ} 21.26^{\prime}$ & $75^{\circ} 08.75^{\prime}$ & $133.5 / 8$ & $5 / 6$ & $5 / 0$ & 1.0 & -21.3 & 132.4 & 6.7 & 2.8 & -15.3 & 132.4 & 6.7 \\
\hline P126 & $15^{\circ} 15.29^{\prime}$ & $75^{\circ} 13.32^{\prime}$ & $319 / 14.5$ & $9 / 9$ & $9 / 0$ & 353.3 & -5.1 & 309.1 & 2.9 & 351.3 & -13.1 & 309.1 & 2.9 \\
\hline P127 & $15^{\circ} 15.29^{\prime}$ & $75^{\circ} 13.32^{\prime}$ & $319 / 14.5$ & $11 / 11$ & $11 / 0$ & 346.0 & -17.2 & 97.6 & 4.6 & 341.1 & -23.3 & 97.6 & 4.6 \\
\hline $\mathrm{P} 128$ & $15^{\circ} 15.29^{\prime}$ & $75^{\circ} 13.32^{\prime}$ & $319.7 / 14.5$ & $9 / 10$ & $9 / 0$ & 356.4 & -18.1 & 120.0 & 4.7 & 351.5 & -26.3 & 120.0 & 4.7 \\
\hline Mean & & & & $18 / 21$ & & 178.9 & 18.8 & 47.5 & 5.1 & 173.3 & 23.2 & 61.2 & 4.5 \\
\hline Mean & \multicolumn{3}{|c|}{$60 \%$ unfolding (see text) } & $18 / 21$ & & - & - & - & - & 176.1 & 21.9 & 69.1 & 4.2 \\
\hline Mean $^{\text {b }}$ & \multicolumn{3}{|c|}{$45 \%$ unfolding (see text) } & $6 / 6$ & & 181.2 & 22.1 & 85.2 & 7.3 & 178.7 & 24.4 & 127.5 & 6.0 \\
\hline \multicolumn{14}{|c|}{ Chilcatay Formation } \\
\hline P101 & $14^{\circ} 12.03^{\prime}$ & $76^{\circ} 08.68^{\prime}$ & $295.9 / 10$ & $10 / 10$ & $4 / 1$ & 342.9 & -25.1 & 20.7 & 11.2 & 339.0 & -32.2 & 20.7 & 11.2 \\
\hline P102 & \multirow{2}{*}{\multicolumn{2}{|c|}{$\begin{array}{l}\sim 20 \mathrm{~m} \text { above } \mathrm{P} 101 \\
\sim 40 \mathrm{~m} \text { above } \mathrm{P} 102\end{array}$}} & $276.9 / 13$ & 9/9 & $9 / 0$ & 357.5 & -20.8 & 24.5 & 10.6 & 356.3 & -33.6 & 24.5 & 10.6 \\
\hline P103 & & & $277.1 / 12$ & $6 / 7$ & $6 / 0$ & 349.8 & -18.5 & 34.9 & 11.5 & 348.1 & -29.9 & 34.9 & 11.5 \\
\hline P104 & $14^{\circ} 11.47^{\prime}$ & $76^{\circ} 08.41^{\prime}$ & $270.2 / 12$ & $5 / 8$ & $5 / 0$ & 343.8 & -28.6 & 154.8 & 6.2 & 341.3 & -40.0 & 154.8 & 6.2 \\
\hline P107 & $14^{\circ} 40.80^{\prime}$ & $75^{\circ} 49.92^{\prime}$ & $133.3 / 32$ & $8 / 8$ & $0 / 2$ & 150.3 & 43.3 & 25.6 & 12.1 & 171.3 & 27.9 & 25.6 & 12.1 \\
\hline P108 & $14^{\circ} 40.80^{\prime}$ & $75^{\circ} 49.92^{\prime}$ & $182.1 / 72.3$ & $9 / 11$ & $8 / 1$ & 332.9 & 12.0 & 26.1 & 10.3 & 337.0 & -18.4 & 50.9 & 7.3 \\
\hline P109-10-11 & $14^{\circ} 40.52^{\prime}$ & $75^{\circ} 49.68^{\prime}$ & $* * / * * \mathrm{c}$ & $11 / 26$ & $1 / 5$ & 164.6 & 49.9 & 14.5 & 12.7 & 158.8 & 33.5 & 16.8 & 11.7 \\
\hline P118 & $14^{\circ} 58.38^{\prime}$ & $75^{\circ} 19.20^{\prime}$ & $278.9 / 7.5$ & $5 / 8$ & $0 / 1$ & 168.8 & 35.4 & 102.6 & 9.5 & 166.6 & 42.4 & 102.6 & 9.5 \\
\hline P119 & $14^{\circ} 58.39^{\prime}$ & $75^{\circ} 22.15^{\prime}$ & $300.0 / 8.5$ & $10 / 10$ & $10 / 0$ & 359.4 & -15.3 & 51.9 & 6.8 & 357.9 & -22.6 & 51.9 & 6.8 \\
\hline P120 & $14^{\circ} 58.39^{\prime}$ & $75^{\circ} 22.15^{\prime}$ & $300 / 8.5$ & $8 / 8$ & $8 / 0$ & 354.9 & -15.9 & 20.7 & 12.5 & 353.2 & -22.8 & 20.7 & 12.5 \\
\hline $\mathrm{P} 121$ & $14^{\circ} 58.39^{\prime}$ & $75^{\circ} 22.15^{\prime}$ & $300 / 8.5$ & $8 / 11$ & $8 / 0$ & 352.9 & -25.2 & 27.7 & 10.7 & 350.0 & -31.9 & 27.7 & 10.7 \\
\hline P122 & $14^{\circ} 58.39^{\prime}$ & $75^{\circ} 22.15^{\prime}$ & $300 / 8.5$ & $8 / 10$ & $8 / 0$ & 348.8 & -17.8 & 62.4 & 7.1 & 346.6 & -24.1 & 62.4 & 7.1 \\
\hline $\mathrm{P} 123 \mathrm{~A}$ & $14^{\circ} 58.39^{\prime}$ & $75^{\circ} 22.15^{\prime}$ & $301.1 / 8.5$ & $6 / 6$ & $3 / 0$ & 357.6 & -19.1 & 29.5 & 13.4 & 355.6 & -26.1 & 29.5 & 13.4 \\
\hline Mean & & & & $13 / 15$ & & 168.5 & 23.6 & 22.8 & 8.9 & 168.0 & 29.8 & 75.7 & 4.8 \\
\hline Mean $^{\mathrm{b}}$ & & & & $5 / 5$ & & 159.7 & 29.1 & 10.6 & 24.6 & 162.4 & 31.0 & 62.8 & 9.7 \\
\hline
\end{tabular}

${ }^{a}$ Note $\lambda s$, site latitude; $\phi s$, site longitude; no/No, number of samples retained in the mean/total number of samples demagnetized; N, R, of the retained samples, number possessing normal $(\mathrm{N})$ or reversed $(\mathrm{R})$ polarity (note that no polarity was assigned to samples whose directions were determined with great circles); D, declination; I, inclination; $\alpha_{95}$, radius of the cone in which the mean direction lies within $95 \%$ confidence; $\mathrm{k}$, best estimate of the precision parameter.

${ }^{\mathrm{b}}$ Mean of the sites containing reversed polarity directions.

${ }^{\mathrm{c}}$ Varying strike and dip, composite site of P109-P110-P111 (see text).

samples have reverse polarity, we suspect that both primary and remagnetized magnetic components are mixed in the site mean directions listed in Table 2. Despite this, we applied field tests to both formations assuming the components were primary. Sample level reversals tests were positive at $95 \%$ confidence for both formations (class C for Chilcatay and B for Pisco); the fold test statistic based on site mean directions for the Chilcatay Formation maximizes at $103 \pm 21 \%$ unfolding (e.g., remanence is prefolding), while that for the Pisco Formation maximizes at $58 \pm$ $16 \%$ unfolding (e.g., remanence is synfolding) (Table 2). The two overall mean directions at $100 \%$ and $60 \%$ unfolding are distinct at 95\% confidence limits [McFadden and Lowes, 1981]. To further test the data we again applied the fold test, but this time selecting only the sites that contain reverse polarities, assuming that they are less affected by a Recent or Bruhnes field overprint. The test statistic for the five Chilcatay sites fulfilling this requirement maximizes at $101 \pm 21 \%$ unfolding while that for the six Pisco sites is at $43 \pm 30 \%$ unfolding, both of which are very similar to their respective results using all site mean directions. Overall mean directions from the sites with reversed directions are indistinct at $95 \%$ confidence limits with the mean of their respective total populations, and again distinct with respect to one another. Thus the most straightforward interpretation is that the overall mean directions are indicative of a primary magnetization for the Chilcatay Formation and a synfolding remanence for the Pisco Formation. As folding of the Pisco Formation, at least near Puente Huamani, is Quaternary [Mercier et al., 1992], the remanence is likely 
Table 3. Paleomagnetic Poles From This Study

\begin{tabular}{|c|c|c|c|c|c|c|c|c|c|c|c|c|c|c|c|}
\hline \multirow[b]{2}{*}{ Study } & \multirow[b]{2}{*}{ Age, Ma } & \multirow[b]{2}{*}{$\lambda,{ }^{\circ} \mathrm{S}$} & \multirow[b]{2}{*}{$\phi,{ }^{\circ} \mathrm{E}$} & \multirow[b]{2}{*}{$\mathrm{N}$} & \multicolumn{4}{|c|}{ Geographic } & \multicolumn{4}{|c|}{ Stratigraphic } & \multicolumn{3}{|c|}{ Pole } \\
\hline & & & & & $\mathrm{Dg}$ & Ig & $\mathrm{k}$ & $\alpha_{95}$ & Ds & Is & $\mathrm{k}$ & $\alpha_{95}$ & $\lambda,{ }^{\circ} \mathrm{S}$ & $\phi,{ }^{\circ} \mathrm{E}$ & $\mathrm{A}_{95}$ \\
\hline Subandean zone (A) & $28-7$ & 6.6 & 283.7 & 9 & 165.4 & 25.1 & 7.8 & 19.6 & 177.8 & 21.8 & 53.8 & 7.1 & 84.7 & 126.6 & 5.9 \\
\hline Cajabamba (B) & $11-8$ & 7.6 & 281.9 & 7 & 157.0 & 15.1 & 61.2 & 7.8 & 155.4 & 13.1 & 141.9 & 5.1 & 65.6 & 192.5 & 4.8 \\
\hline $\operatorname{San} \operatorname{Marcos}(\mathrm{C})$ & $11-8$ & 7.3 & 281.9 & 7 & 186.5 & 11.6 & 29.3 & 11.3 & 186.0 & 19.3 & 68.8 & 7.3 & 83.4 & 35.8 & 6.6 \\
\hline CdH (above) (D) & $\sim 4-3$ & 9.6 & 282.5 & 6 & 174.8 & 12.4 & 372.3 & 3.5 & 173.5 & 15.0 & 284.8 & 4.0 & 83.3 & 208.8 & 2.7 \\
\hline CdH (below) (D) & $\sim 5-4$ & 9.6 & 282.5 & 6 & 168.2 & 17.2 & 62.1 & 8.6 & 162.4 & 21.7 & 62.1 & 8.6 & 72.7 & 185.5 & 8.2 \\
\hline Pisco Fm $(\mathrm{E})^{* *}$ & $\sim 3-0$ & 14.5 & 284.5 & 18 & 178.9 & 18.8 & 47.5 & 5.1 & 176.1 & 21.9 & 70.2 & 4.2 & 85.1 & 231.6 & 3.5 \\
\hline Pisco Fm $(\mathrm{E})^{* * * b}$ & $\sim 3-0$ & 14.5 & 284.5 & 26 & 178.2 & 20.1 & 55.3 & 3.8 & 176.3 & 22.2 & 69.1 & 3.4 & 85.3 & 231.5 & 2.9 \\
\hline Chilcatay $\mathrm{Fm}(\mathrm{F})^{\mathrm{c}}$ & $30-17$ & 14.7 & 284.3 & 18 & 167.3 & 23.5 & 30.3 & 6.4 & 166.5 & 28.5 & 79.3 & 3.9 & 77.0 & 190.0 & 3.3 \\
\hline
\end{tabular}

${ }^{a}$ Note $\lambda$, latitude; $\phi$, longitude; $N$, number of sites; $\alpha_{95}\left(\mathrm{~A}_{95}\right)$, radius of the cone in which the mean direction (pole) lies within $95 \%$ confidence; reference poles $\left(\lambda, \phi, \mathrm{A}_{95}\right)$ for $0(86.5,162.3,2.5), 10(85.8,150.0,1.9)$, and $20(84.7,135.5,2.6)$ [Besse and Courtillot, 2002], relative to the mean age of the study; $\mathrm{CdH}$, Callejon de Huaylas. All poles were calculated from tilt-corrected data at $100 \%$ unfolding except for the Pisco Fm. as indicated by ** (60\%) and $* * *(45 \%)$.

${ }^{b}$ Poles of this study combined with eight sites of Tsunakawa et al. [1987].

${ }^{\mathrm{c}}$ Poles of this study combined with five sites of Macedo-Sánchez et al. [1992].

post- 2 Ma yet pre- 0.7 Ma because some samples from Puente Huamani possess reverse polarities and therefore the remanence should be pre-Bruhnes.

\section{Interpretation and Discussion}

\subsection{South American Reference Poles}

[25] The South American apparent polar wander path (APWP) is constrained by few reliable Tertiary paleomagnetic data from the craton. One method to overcome this deficiency is to use a synthetic South American APWP derived from poles from other continents. We used the most recent compilation by Besse and Courtillot [2002], which incorporates two times more data than their previous work [Besse and Courtillot, 1991] as well as much improved oceanic plate kinematic parameters, and thus further decreases uncertainties on both the age and error envelope for each pole. Other South American APWPs have been proposed [Beck, 1998; Randall, 1998], but their poles average larger time windows and have greater uncertainties. Note that the Besse and Courtillot [2002] synthetic APWP reinforces earlier conclusions that the South American Plate underwent very little apparent polar wander from the Cretaceous to the Present. The reference poles and the overall study mean poles from this study are listed in Table 3. In the discussion below, tectonic inferences are based on paleomagnetic rotations, which were calculated following the procedures of Coe et al. [1985].

\subsection{Subandean Zone}

[26] Relative to the $20 \mathrm{Ma}$ reference pole (Table 3), which is the average time spanned by the Ipururo and Chambira formations, no significant rotation is recorded $(+0.6 \pm 5.1)$. The Ipururo and Chambira pole $\left(84.7^{\circ} \mathrm{S}\right.$, $306.6^{\circ} \mathrm{E}, \mathrm{A}_{95}=5.9^{\circ}$ ) is virtually identical to the reference pole and with the 5 to $24 \mathrm{Ma}$ reference pole from Randall [1998] $\left(85^{\circ} \mathrm{S}, 310^{\circ} \mathrm{E}, \mathrm{A}_{95}=5^{\circ}\right)$ and the sole late Miocene pole available for stable South America $\left(85^{\circ} \mathrm{S}, 316^{\circ} \mathrm{E}, \mathrm{A}_{95}=\right.$ $\left.8^{\circ}\right)$ [Schultz et al., 1986]. This means that late Miocene to
Present folding and thrusting in the Tarapoto region did not involve vertical axis block rotation and thus the Tarapoto pole can be considered as a reference South American pole for the late Oligocene to earliest Pliocene. It also helps to define the northeastern limit of the counterclockwise rotations in the Peruvian Cordillera.

\subsection{Western Cordillera Basins}

\subsubsection{Cajabamba and San Marcos Basins}

[27] In the Western Cordillera, the Cajabamba basin shows significant counterclockwise rotation $-21.4^{\circ} \pm 4.1^{\circ}$ relative to stable South America. For the San Marcos basin, the overall mean pole based on $100 \%$ unfolding of 7 sites (Table 3) is rotated $+9.2^{\circ} \pm 5.4^{\circ}$ clockwise with respect to the $10 \mathrm{Ma}$ reference pole. The overall mean pole based on $72 \%$ unfolding of 8 sites $\left(86.2^{\circ} \mathrm{S}, 217^{\circ} \mathrm{E}, \mathrm{A}_{95}=7.6^{\circ}\right)$ records a smaller clockwise rotation $\left(+6.5^{\circ} \pm 6.2^{\circ}\right)$ with respect to the same reference pole (since sedimentation and tilting were roughly coeval). As both poles yield similar results, tectonic interpretations are independent of which is used and we employ the one based on $100 \%$ unfolding of seven sites.

[28] As stated above, Mitouard et al. [1990, 1992] obtained reliable paleomagnetic data from 58 sites of Cretaceous to upper Eocene rocks in the Cajamarca deflection. All sites west of Cajabamba are rotated significantly counterclockwise, with a mean of $-31.4^{\circ} \pm 6.6^{\circ}$ for the Cretaceous $(\mathrm{N}=31)$ and $-22.3^{\circ} \pm 4.9^{\circ}$ for the Cenozoic (up to circa $35 \mathrm{Ma}, \mathrm{N}=20$ ) (Figure $2 \mathrm{~b}$ ) (rotations calculated using the Besse and Courtillot [2002] APWP). They found that the magnitude of rotation was coherent throughout the Cajamarca deflection, independent of fold axis trends. Thus the folds were created, then the region rotated after the late Eocene. Although the Cretaceous rocks appear slightly more rotated than the Cenozoic rocks, the two populations are not distributed uniformly over the same area, as the Cenozoic sites were collected mostly in the western part of the deflection. Cretaceous sites there $(\mathrm{N}=13)$ record a rotation of $-25.0^{\circ} \pm 8.0^{\circ}$, very similar to the Cenozoic 
rotation of $-22.3^{\circ} \pm 4.9^{\circ}$, suggesting that no significant rotation occurred between the two time series. East of Cajabamba, 7 Cretaceous sites were only slightly rotated $\left(-7.7^{\circ} \pm 6.6^{\circ}\right)$ (Figure 2b).

[29] Our results from the northern basins are shown together with the data of Mitouard et al. [1990, 1992] in Figure $2 b$, where it is seen that the Cajabamba basin is rotated the same amount as the older rocks to the west. Just east of the Cajabamba basin, Mitouard et al. [1992] found only very slight rotation of Cretaceous strata, suggesting a structural discontinuity should separate them from the rotated Cajabamba basin. Such a structure, the Chaquilbamba fault, has indeed been identified by Bellier et al. [1989] (Figure 2b). On the other hand, the San Marcos basin is slightly clockwise rotated, consistent with the finding of Bellier et al. [1989] that this basin is surrounded by several structures including seismogenic normal faults (e.g., faults S10 and S14 from Bellier et al. [1989]) (Figure 2b) that could have accommodated the rotation.

[30] Figure 2c shows one interpretation of how the pattern of rotations could be produced in a tectonic regime dominated by compression with a minor sinistral shear component. The modified bookshelf fault model suggests E-W compression was taken up mostly on NNW-trending structures (i.e., the Marañón fold and trust belt) while the shear and associated block rotation is accommodated by F2 faults that exploited the preexisting, E-W-trending structures particular to the Cajamarca deflection. The model implies that the F2 faults (and folds) rotated $\sim 20^{\circ}$ counterclockwise except close to their intersection with the F1, NNW-striking thrusts. We suggest that the Cajabamba basin sediments were deposited on a rotating block, when the Chaquilbamba thrust fault was reactivated as a normal fault [Bellier et al., 1989], whereas the San Marcos basin formed in an accommodation structure under combined pull-apart and rightlateral shear from the F2 structures.

\subsubsection{Callejón de Huaylas Basin}

[31] Two interpretations of the Callejón de Huaylas paleomagnetic data are possible. Either they represent a (Pliocene?) remagnetization, or the section should be divided into two parts based on structural and magnetic characteristics. Considering the former option, the in situ $(0 \%$ unfolding) pole based on 12 sites indicates a small counterclockwise rotation of $-5.3^{\circ} \pm 3.7^{\circ}$ when compared against the recent South American reference pole (Table 3). Cutting the Lloclla Formation above and below the angular unconformity yields paleomagnetic poles of $83.3^{\circ} \mathrm{S}, 28.8^{\circ} \mathrm{E}, \mathrm{A}_{95}=$ $2.7^{\circ}$ and $72.7^{\circ} \mathrm{S}, 5.5^{\circ} \mathrm{E}, \mathrm{A}_{95}=8.2^{\circ}$, respectively (Table 3 ). Relative to the recent South American reference pole, the horizons with dips $>10^{\circ}$ show a significant counterclockwise rotation of $-14.5^{\circ} \pm 6.8^{\circ}$ whereas the overlying beds with dips $<10^{\circ}$ record a slight counterclockwise rotation of $-3.4^{\circ} \pm 2.9^{\circ}$. As noted above, the sum of the geologic and paleomagnetic data support cutting the section into two parts, suggesting that the bulk of rotation occurred when the rocks below the angular unconformity were tilted. This is potentially a highly significant observation because it would directly link the paleomagnetic rotations to mountain building, as the Cordillera Blanca batholith was likely exhumed from circa 5 to 3 Ma [Petford and Atherton, 1992]. Moreover, muscovite extracted from mylonite in the Cordillera Blanca shear zone yielded a ${ }^{40} \mathrm{Ar} /{ }^{39} \mathrm{Ar}$ date of $3.6 \pm 0.1 \mathrm{Ma}$ [Petford and Atherton, 1992]. The ductile fabric in the shear zone records oblique motion with a minor component of left-lateral strike slip in addition to pure dip slip, as slickenside lineations are slightly oblique to the dip of foliation [Petford and Atherton, 1992]. Thus, if the circa $5 \mathrm{Ma}$ whole rock K-Ar dates of the volcanic tuff from the base of the Lloclla Formation are correct, the deposition of the series and concomitant counterclockwise rotation are linked to sinistral shear and extension on the Cordillera Blanca fault, which clearly accommodated exhumation of the batholith.

\subsection{Pisco Basin}

[32] Our paleomagnetic data from the Pisco basin suggest that the upper Oligocene to lower Miocene Chilcatay Formation sediments possess prefolding primary magnetizations. Macedo-Sánchez et al. [1992] reported six sites of siliceous tuffs from the basin near Nazca City dated at 19 to $22 \mathrm{Ma}$ (Figure 4), of which five sites were thought to possess primary magnetizations. The tilt corrected mean direction $\left(\mathrm{D}=163.1^{\circ}, \mathrm{I}=25.0^{\circ}, \alpha_{95}=7.0^{\circ}\right)$ is indistinguishable from our overall site mean direction $\left(\mathrm{D}=168.0^{\circ}\right.$, $\mathrm{I}=29.8^{\circ}, \alpha_{95}=4.8^{\circ}$ ); thus we combined their five sites with our 18 sites to calculate an upper Oligocene to lower Miocene pole (Table 3 ). With respect to stable South America, the Pisco basin rotated $-10.6^{\circ} \pm 3.4^{\circ}$ counterclockwise since the lower Miocene. This is likely a minimum amount of rotation because, as we suspect that our site mean directions are contaminated by the present-day or recent field, the magnetic vectors would be pulled away from the rotated direction toward the north. This is suggested by both the mean direction based on our reversed site population (only) and from the Macedo-Sánchez sites, which are all reversed and slightly more counterclockwise rotated.

[33] Tsunakawa et al. [1987] reported two site mean directions from the Pisco Formation at Puente Huamani as well as data for six other sites from the Pisco and Changuillo formations (now considered equivalent to the Pisco Formation [see Dunbar et al., 1990]) (Figure 4). The test statistic based on their 8 sites maximizes at $3 \pm 21 \%$ unfolding. Because more than half of their samples have reversed polarities, a postfolding age of remanence could be due to erroneous tilt-correction as we note, for example, a discrepancy between their bedding attitudes and ours at Puente Huamani. Nevertheless, we combined their eight sites with ours and reapplied the fold test; the test statistic maximizes at $43 \pm 13 \%$ unfolding. When calculating an overall Quaternary yet pre-Bruhnes pole for the Pisco basin, the result changes little whether the Tsunakawa et al. [1987] data are included or not (Table 3). Compared against the recent pole from South America, there is no significant rotation for $\mathrm{N}=18$ sites (at $60 \%$ unfolding, $-0.8^{\circ} \pm 3.4^{\circ}$ ) or for $\mathrm{N}=26$ sites (at $45 \%$ unfolding, $-0.6^{\circ} \pm 3.1^{\circ}$ ) since circa $1 \mathrm{Ma}$. Taken together, these data imply that the age of 
rotation of the Chilcatay Formation is post- circa 15 Ma yet pre-Bruhnes (circa $0.7 \mathrm{Ma}$ ).

[34] In summary, our study has identified significant counterclockwise rotations in Cretaceous to upper Neogene rocks from $15.5^{\circ} \mathrm{S}$ to $7^{\circ} \mathrm{S}$ (Figure 1). At the Cajamarca deflection (Figures 1 and 2), where structures cut the Andean trend at high angles, a bookshelf mechanism likely acted to produce the rotations there, in a manner similar to that found in the Chilean forearc [e.g., Beck, 1998; Randall, 1998; Abels and Bischoff, 1999]. On the other hand, south of the Cajamarca deflection $\left(\sim 8.5^{\circ} \mathrm{S}\right)$, no large-scale crosscutting structures are recognized, and rotation sense and magnitude are uniform until reaching the Abancay deflection, where again, large crosscutting structures are recognized. Our new data thus strengthen the hypothesis, previously suggested by Rousse et al. [2002], that the region between circa $15.5^{\circ} \mathrm{S}$ and $8.5^{\circ} \mathrm{S}$ rotated as a coherent block. To the east, approaching the Marañón fold and thrust belt (Figure 1), the pattern of counterclockwise rotation begins to break down. Farther east in the Subandean fold and thrust belt, no rotation is observed. Therefore we propose that the area of dense thrust faults that comprise the Marañón fold and thrust belt likely represents a first-order tectonic boundary. This hypothesis predicts that the older system of thrust faults within the Marañon belt was reactivated in the late Cenozoic, partially accommodating the block rotations. A similar conclusion was reached for the paleomagnetic rotations found in the northern Altiplano, where the transition between the Altiplano and the Eastern Cordillera appears to have played an important role in facilitating the rotations there [Gilder et al., 2003]. Another important observation is that north of the Abancay deflection, all rotations recorded in Cretaceous to Neogene rocks are of the same magnitude, suggesting that the rotations are linked to a late MiocenePliocene deformation event. Paradoxically, this implies that the other well recognized and intense post-Cretaceous yet pre-Mio-Pliocene deformation episodes did not result in vertical axis block rotations, raising an important question as to what controls block rotation during orogenesis.

\subsection{Nazca-South American Plate Reconstruction}

[35] To understand the origin of the relatively youthful rotations, we reconstructed the relative and absolute motion between the Nazca (NAZ) and South America (SA) plates since $20 \mathrm{Ma}$ (Figure 8). We used the global circuit of NAZAntarctica (ANT)-Africa (AF)-SA, using the kinematic parameters for SA-AF [Müller et al., 1997], AF-ANT [Patriat and Segoufin, 1988] and ANT-NAZ [Tebbens and Cande, 1997] and interpolated over 5 Myr windows (model R02C). We compared our circuit to that of Somoza [1998] (model S98C), who used different kinematic parameters for AF-ANT [Norton, 1995] and SA-AF [Cande et al., 1988]. We also took an independent approach by using hot spots to anchor the AF Plate to the Atlantic (ATL) hot spots and the Pacific (PAC) Plate to the Pacific hot spots [Duncan and Richards, 1991; Raymond et al., 2000]. We then used the $\mathrm{SA}-\mathrm{AF}$ relative plate motion kinematics to move SA and
PAC-NAZ kinematics to move NAZ [Mayes et al., 1990] (model R02A). This method assumes no relative motion between ATL and PAC hot spots. We then calculated the convergence rate and direction for two points at $7.5^{\circ} \mathrm{S}$, $278.8^{\circ} \mathrm{E}$ and $13^{\circ} \mathrm{S}, 281.8^{\circ} \mathrm{E}$ for all three models (Figure $8 \mathrm{~b}$ ). Although we are conscious the uncertainties are large (2030\%) [Pardo-Casas and Molnar, 1987] and difficult to quantify, the three independent reconstructions using the most recent kinematic data show similar trends and give us confidence in interpreting changes in convergence parameters. In addition, these trends are consistent over the past 3 Ma when comparing NUVEL-1A [DeMets et al., 1994] with modern space geodetic data [Angermann et al., 1999; Norabuena et al., 1999].

[36] In the plate reconstruction (Figure 8) we show the northernmost possible extension of the Nazca Ridge considering it as the mirror of the Tuamotu Ridge [Pilger, 1981; von-Huene and Lallemand, 1990; Hampel, 2002]. Note that the Nazca Ridge cannot extend north of the Mendana fracture zone (Figure 8,0 Ma) because the age of the oceanic crust north of the fracture zone is younger than the age of the hot spot defining the Nazca Ridge. On the basis of our calculations, we find that the head of the Nazca Ridge began colliding with the South American Plate at around $10 \mathrm{Ma}$ (Figure 8). This is entirely compatible with the reconstruction of Hampel [2002], who found that ridge subduction began at $11.2 \mathrm{Ma}$ at $11^{\circ} \mathrm{S}$ using the plate circuit of Somoza [1998]. Of noted significance is that, in each of the three models, the convergence rates decrease significantly $(\sim 27 \%)$ and the convergence angles rotate counterclockwise by $\sim 12^{\circ}$ after $10 \mathrm{Ma}$, precisely the time, sense, and magnitude of paleomagnetic rotations documented throughout the Western Cordillera.

[37] Today, the Nazca Ridge is imaged tomographically under the Peruvian Andes as a $1500 \mathrm{~km}$-long zone where the Nazca Plate is essentially flat lying, extending over $500 \mathrm{~km}$ inland of the subduction zone [Norabuena et al., 1994; Gutscher et al., 2000]. Interestingly, this region lacks active volcanism and has high seismic Q-paths, implying negligible asthenosphere between it and the overlying continental lithosphere [Sacks, 1983]. This could suggest that the coherence in time and space between the collision of the Nazca Ridge and the changes in plate motion are due to a cause and effect relationship. Thus the paleomagnetic rotations and a significant part of the structural deformation seen in the Peruvian Andes would be an expression of the increased lithospheric coupling due to the collision of the buoyant Nazca Ridge with South America. It is interesting to note that the limit between the Western and Eastern Cordillera, which marks the transition from rotated and nonrotated regions, coincides with the approximate "knee" in the subducted slab, east of which the slab descends with a more normal $\sim 30^{\circ}$ subduction angle, and where the athenospheric wedge is reestablished. Thus the Western Cordillera plausibly represents the 'forearc region', with the boundary between the Western and Eastern Cordillera largely decoupling trench-parallel and trench normal motion, as has been observed in many other of the world's island arc systems [McCaffrey, 1992]. Seen in this way, the subducting plate 


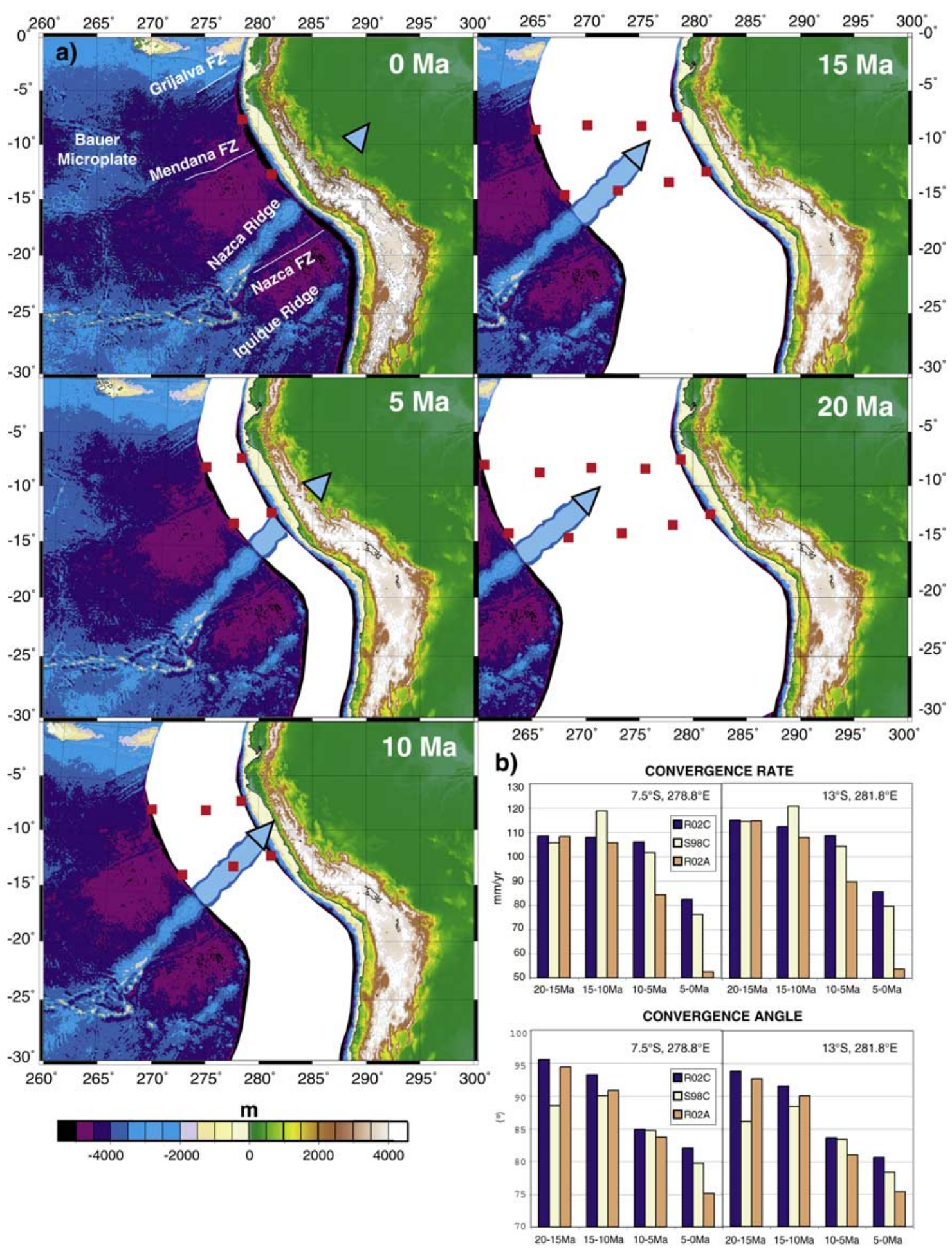

Figure 8. (a) Plate reconstruction of Nazca (NAZ)-South America (SA) relative motion (SA fixed) averaged over 5 Myr time windows. Triangles represent the northernmost tip of the Nazca Ridge. Red squares are the trajectories of the two points calculated with model R02C. (b) Convergence rates and angles calculated for two points from the Peruvian trench for each $5 \mathrm{Myr}$ time window. Parameters were calculated from the plate circuit (R02C), from the model using a hot spot reference frame (R02A) (see text), and from Somoza [1998] (S98C). 
controls forearc motion relative to the craton, whereas the backarc responds to impingement from the forearc, resulting in thin skin dominated deformation. A similar kinematic model was suggested by Roperch et al. [2000] to explain the development of the Bolivian Orocline in the Oligo-Miocene.

\subsection{Deformation of the Peruvian Margin and Conclusions}

[38] A synthesis of the paleomagnetic rotations, the stress directions as defined by the bedding attitudes of the paleomagnetic sites, and the position of the Nazca Ridge through time are shown in Figure 9, together with a plot of rotation age versus latitude. Two main questions arise from the data: (1) did the deformation (and the rotations) propagate, or (2) was the deformation more punctual in time and space over the past $10 \mathrm{Ma}$ ? For the former, a south to north propagation is suggested by the rotation ages in Ayacucho and Callejón de Huaylas, and by a Permo-Triassic result from the Bagua Grande region $\left(\sim 6^{\circ} \mathrm{S}\right)$ that shows neither significant rotation nor latitudinal transport since $\sim 250 \mathrm{Ma}$ [Gilder et al., 2003]. If true, this would imply that the deformation path is anti-correlated with the subduction of the Nazca Ridge, which migrated southward (Figure 9). It is also coherent with the idea that deformation began near the Bolivian Orocline and propagated away from it, as suggested by the gradient in shortening [Isacks, 1988; Beck et al., 1996; Kley and Monaldi, 1998] and older paleomagnetic rotations found along the coast of the Bolivian Orocline [Arriagada et al., 2000; Roperch et al., 2000; Somoza and Tomlinson, 2002].

[39] However, there are several arguments against hypothesis 1 that would tend instead to support hypothesis 2 . The first is the state of stress. For the localities displaying significant counterclockwise rotation, often the maximum compression or extension direction parallels the NazcaSouth American plate convergence direction (Figure 9). Although the detailed strain history is more complicated in detail [Sébrier et al., 1988; Mercier et al., 1992], the fold axes defined by the bedding attitudes can represent the cumulative strain experienced by the rocks since deposition. The main point is that the extensional or compressional regime in which rotation occurred is largely related to the stress-strain field imposed by the subducting Nazca Plate and its degree of coupling with the overriding South American Plate [cf. McNulty and Farber, 2002]. Moreover, the systematic counterclockwise sense of rotation is consistent with the convergence direction force couple [McCaffrey, 1992] (Figure 8). The fact that counterclockwise rotation occurs in either extensional or compressional stress regimes favors a large-scale mechanism, again probably linked to coupling of the flat slab, which presently underlies the entire area affected by rotation [Gutscher et al., 2000]. Heterogeneities in the upper plate may cause aberrations in the way it responds to the subducting plate, such as in Cajamarca. Indeed, the larger rotation of the Cajabamba basin suggests that the mechanism causing the rotation there did not propagate from the Bolivian Orocline, but instead was more locally controlled.
[40] If hypothesis 2 is valid, then the rotations occurred in a restricted time window. Given the large spatial extent of the sampling, and the coherence of the rotations from $\sim 15.5^{\circ} \mathrm{S}$ to $8.5^{\circ} \mathrm{S}$, the simplest explanation is that the region rotated as a coherent block. This is supported by the absence of mapped, large-scale faults that crosscut the dominant structural trend of the Andes, which would be necessary to evoke a smaller scale block rotation model. Further, the large block model predicts that shortening amounts should decrease from south to north, which is consistent with geologic observations [Isacks, 1988; Kley and Monaldi, 1998]. This in turn suggests that the changes in shortening seen in the Bolivian Orocline and those in Peru north of the Abancay deflection arise from different processes, likely generating more complicated structural interactions at the intersection of these two domains. The model further suggests that, from circa 8 to $4 \mathrm{Ma}$, a large portion of the Nazca-South American plate convergence was accommodated by shortening to the east of the block, in the Eastern Cordillera and Subandean Zone, and not within the WadatiBenioff zone [cf. Rousse et al., 2002]. Finally, among the most convincing evidence that paleomagnetic rotations and mountain building are intimately linked are the observations that (1) the northern limit of the paleomagnetic rotations exists where the topography is subdued (less than $3000 \mathrm{~m}$ ), (2) the correlation of paleomagnetic rotation coinciding with exhumation of the Cordillera Blanca batholith and (3) the link between paleomagnetic rotation and deformation that formed geologic structures which define the Andes (e.g., the Ayacucho basin). This situation in central Peru is different from that south of the Abancay deflection (Arica) where convergence direction is orthogonal to the margin and where faults dissect the dominant regional structural trends. There, local fault geometry has a large impact on the presence (and sense) or absence of rotation.

[41] Still, hypothesis 2 cannot account for all the observations either. For example, at $8 \mathrm{Ma}$, when the Ayacucho basin was rotating and deforming, the Nazca Ridge had only subducted for $\sim 2 \mathrm{Myr}$ and was relatively far to the north (Figure 9). However, if one accepts a lag of a few million years after initial contact, there seems to be a close relationship between the paleomagnetic rotations and subduction of the Nazca Ridge. Moreover, because rotation magnitudes in Cretaceous to upper Miocene rocks are the same, there must be some reason particular to the last $10 \mathrm{Ma}$ which favors producing rotation. It is unlikely to be a simple matter of convergence direction alone, which has remained relatively constant over the last circa $45 \mathrm{Ma}$ [Pardo-Casas and Molnar, 1987]. This is why the collision of the Nazca Ridge seems to be a compelling phenomenological cause.

[42] Our new model for the Miocene development of the Peruvian Andes further strengthens the notion [Pilger, 1981; Sacks, 1983] that buoyant slabs, such as the Nazca Ridge segment, profoundly affect the style and nature of tectonics at continent-ocean plate margins. However, one must then explain the more significant shortening in the Bolivian Orocline. Interestingly, a reconstruction of the proto Juan Fernandez hot spot chain suggests that it began subducting off the coast of South America at circa $25 \mathrm{Ma}$ at 


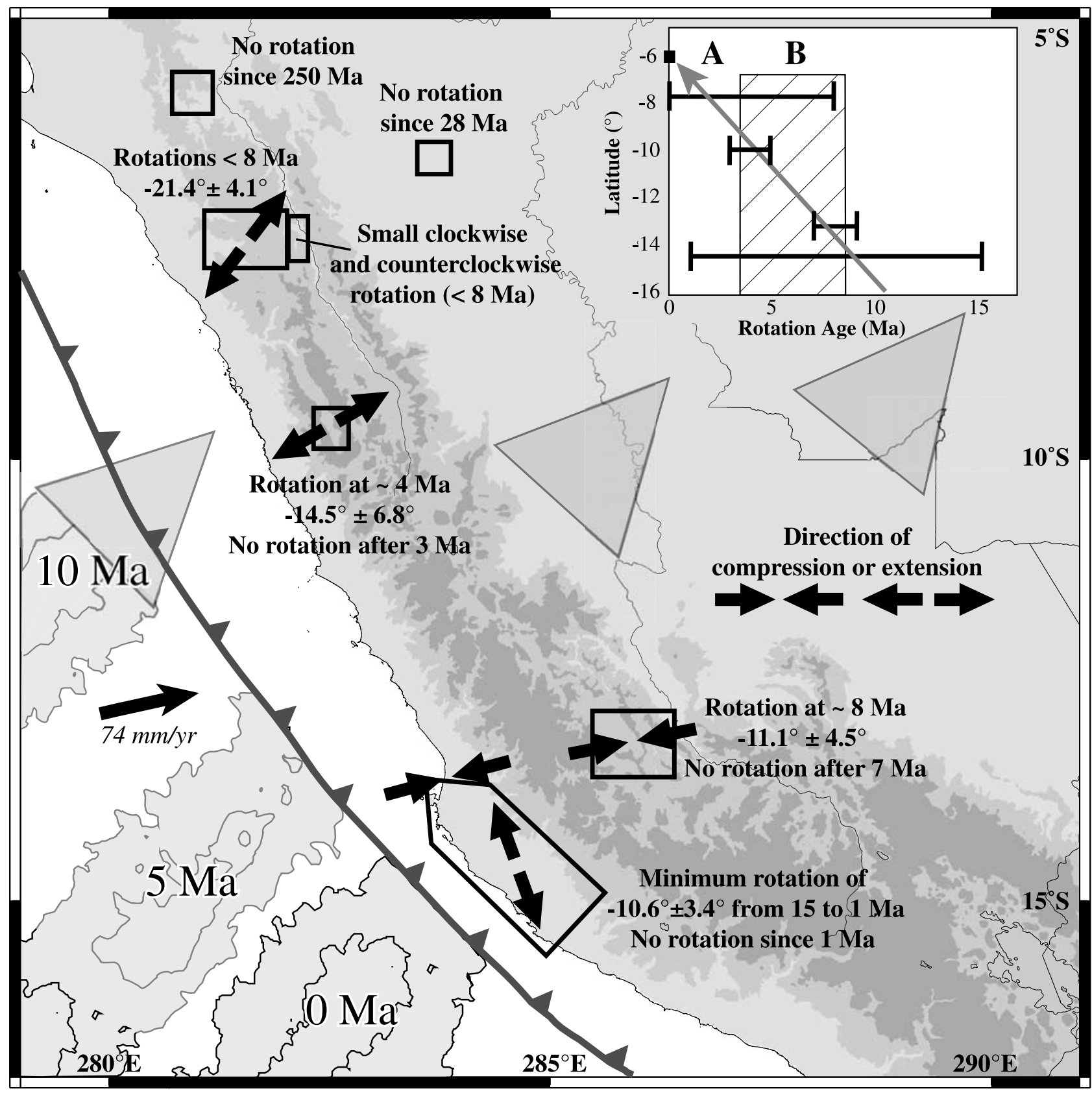

Figure 9. Summary of the paleomagnetic rotations and maximum compression or extension directions from this study. The position of the Nazca Ridge through time is from the model R02C; the present relative convergence vector is from Nuvel-1A [DeMets et al., 1994]. Dark (light) shading is $4000 \mathrm{~m}$ $(2000 \mathrm{~m})$ elevation contour. Inset shows the two hypotheses that can explain the pattern of paleomagnetic rotations from the Western Cordillera and Coastal Zone: A, propagation of deformation from south to north, or B, a more punctual and widespread event in the $\sim 8$ to 4 Myr window.

$\sim 19^{\circ} \mathrm{S}$, near the center of the Bolivian Orocline [Yáñez et al., 2001]. Such a collision at circa $25 \mathrm{Ma}$ is consistent with the timing of deformation and paleomagnetic rotations seen in the forearc [Roperch et al., 2000], which leads us to speculate that part of the Bolivian Orocline formation could indeed be related to ridge subduction. If our prediction is correct, it implies that slab coupling and concomitant mountain building are most pronounced at the beginning stages of ridge subduction, whence the subduction is inhibited. The system then evolves to a more normal subduction regime, probably when it becomes more energetically favorable to renew subduction rather than build additional topography through tectonic shortening. As the ridge continues to subduct, significant changes in ridge strike relative to the margin, or possibly major changes in ridge topography, can increase coupling, and thus compres- 
sive deformation, such as the case for the Juan Fernandez ridge at circa $8 \mathrm{Ma}$ at $32^{\circ} \mathrm{S}$ [Yánez et al., 2001]. Ridge collisions could have lasting effects on the affected area by weakening the crust to the point that more deformation can be produced with less stress, which would explain why the Subandean Zone remains active in the Bolivian Orocline region, for example. In this way, the modern Andes would be composed of distinct parts, each of which was molded by a succession of buoyant ridge collisions, with the Juan Fernandez ridge being partly responsible for shaping the Bolivian Orocline at circa $25 \mathrm{Ma}$, the Nazca ridge for the
Peruvian Andes north of the Abancay deflection $\left(15.5^{\circ} \mathrm{S}\right)$ until about $7^{\circ} \mathrm{S}$ at circa 8 to $4 \mathrm{Ma}$, and the Carnegie ridge for the recent deformation seen in the Northern Andes [Gutscher et al., 1999].

[43] Acknowledgments. Software used for paleomagnetic data analysis was developed by Cogné et al. [2003] and R. Enkin (unpublished). Some figures were generated by GMT, written by P. Wessel and J. Smith. Helpful reviews by N. Kukowski and P. Roperch and discussions with Bob Butler and Vincent Courtillot are much appreciated. We thank INSU-CNRS program Interieur de la Terre, IGPP-LLNL, and the US NSF (EAR 9802825 and EAR 0126309) for supporting this project. IPGP contribution 1912.

\section{References}

Abels, A., and L. Bischoff, Clockwise block rotations in northern Chile: Indications for a large scale domino mechanism during the middle-late Eocene, Geology, 27, 751-754, 1999.

Angermann, D., J. Klotz, and C. Reigber, Space-geodetic estimation of the Nazca-South America Euler vector, Earth Planet. Sci. Lett., 171, 329-334, 1999.

Arriagada, C., P. Roperch, and C. Mpodozis, Clockwise block rotations along the eastern border of the Cordillera de Domeyko, northern Chile $\left(22^{\circ} 45^{\prime}-\right.$ $\left.23^{\circ} 30^{\prime} \mathrm{S}\right)$, Tectonophysics, 326, $153-171,2000$

Aubry, L., P. Roperch, M. de Urreiztieta, E. Rossello, and A. Chauvin, Paleomagnetic study along the southeastern edge of the Altiplano-Puna Plateau: Neogene tectonic rotations, J. Geophys. Res., 101, $17,883-17,899,1996$.

Audebaud, E., et al., Les traits Géologiques essentiels des Andes Centrales (Pérou-Bolivie), Rev. Geogr. Phys. Geol. Dyn., 15, 73-113, 1973.

Beck, M. E., Analysis of Late Jurassic-Recent paleomagnetic data from active plate margins of South America, J. South Amer. Earth Sci., 1, 39-52, 1988.

Beck, M. E., On the mechanism of crustal block rotations in the central Andes, Tectonophysics, 299, 75-92, 1998.

Beck, S. L., et al., Crustal-thickness variations in the central Andes, Geology, 24, 407-410, 1996.

Bellier, O., M. Sébrier, F. Gasse, E. Fourtanier, and I. Robles, Evolution géodynamique mio-pliocène et quaternaire des bassins de la cordillère occidentale du Nord-Pérou: Les bassins de Cajabamba, San Marcos et Namora (département de Cajamarca), Geodynamique, 4, 93-118, 1989.

Besse, J., and V. Courtillot, Revised and synthetic apparent polar wander paths of the African, Eurasian, North American, and Indian plates, and true polar wander since $200 \mathrm{Ma}$, J. Geophys. Res., 96, 4029-4050, 1991

Besse, J., and V. Courtillot, Apparent and true polar wander and the geometry of the geomagnetic field in the last $200 \mathrm{Myr}$, J. Geophys. Res., 107, 2300, doi:10.1029/2000JB000050, 2002.

Bonnot, D., Neotectonique et tectonique active de la Cordillère Blanche et du Callejón de Huaylas, Andes Nord-peruviennes, Ph.D. thesis, 115 pp., Univ. Paris XI, Orsay, France, 1984.

Bonnot, D., M. Sebrier, and J. Mercier, Evolution géodynamique plio-quaternaire du bassin intracordillerain du Callejón de Huaylas et de la Cordillère Blanche, Pérou, Geodynamique, 3, 57-83, 1988.

Butler, R. F., D. R. Richards, T. Sempere, and L. G. Marshall, Paleomagnetic determinations of verticalaxis tectonic rotations from late Cretaceous and Paleocene strata of Bolivia, Geology, 23, 799802, 1995

Cande, S. C., J. L. LaBrecque, and W. L. Haxby, Plate Kinematics of the South Atlantic: Chron C34 to
Present, J. Geophys. Res., 93, 13,479-13,492, 1988.

Carey, S. W., The orocline concept in geotectonics, Proc. R. Soc. Tasmania, 89, 255-288, 1955.

Cobbing, E. J., W. S. Pitcher, J. J. Wilson, J. W. Baldock, W. P. Taylor, W. McCourt, and N. J. Snelling, The Geology of the Western Cordillera of Northern Peru, Overseas Mem., vol. 5, 143 pp., Nat. Environ. Res. Counc., London, 1981

Cobbing, J., A. Sanchez, W. Martinez, and H. Zarate, Geologia de los cuadrangulos de Huaraz, Recuay, La Union, Chiquian y Yanahuanca; hojas 20- $h, 20$ i, 20-j, 21-i, 21-j, Bol. Inst. Geol. Min. Metal., Ser A, Carta Geol. Nac. Rep., vol. 76, 286 pp., Inst. Geol. Min. y Metal., Lima, Peru, 1996.

Coe, R. S., B. R. Globerman, P. W. Plumley, and G. A Thrupp, Paleomagnetic results from Alaska and their tectonic implications, in Tectonostratigraphic Terranes of the Circum-Pacific Region, Earth Sci. Ser, vol. 1, edited by D. G. Howell, pp. $85-108$, Circum-Pac. Counc. for Energy and Miner. Resour., Houston, Tex., 1985.

Cogné, J. P., PaleoMac: A Macintosh ${ }^{\mathrm{TM}}$ application for treating paleomagnetic data and making plate reconstructions, Geochem. Geophys. Geosyst., 4(1), 1007, doi:10.1029/2001GC000227, 2003.

Davila, M. F., Geologia de los cuadrangulos de Pisco Guadalupe, Punta Grande, Ica y Cordova. Hojas: 28-k, 28-l, 29-k, 29-l, 29-m, Bol. Inst. Geol. Min. Metal., Ser. A, Carta Geol. Nac. Rep., vol. 47, 62 pp., Inst. Geol. Min. y Metal., Lima, Peru, 1993.

DeMets, C., R. G. Gordon, D. F. Argus, and S. Stein, Effect of recent revisions to the geomagnetic reversal time scale on estimates of current plate motions, Geophys. Res. Lett., 21, 2191-2194, 1994.

Devries, T. J., Oligocene deposition and Cenozoic sequence boundaries in the Pisco Basin (Peru), J. S. Am. Earth Sci., 11, 217-231, 1998.

Dorbath, C., Velocity structure of the Andes of centra Peru from locally recorded earthquakes, Geophys. Res. Lett., 23, 205-208, 1996.

Dunbar, R. B., R. C. Marty, and P. A. Baker, Cenozoic marine sedimentation in the Sechura and Pisco basins, Peru, Palaeogeogr. Palaeoclimatol. Palaeoecol., 77, 235-261, 1990.

Duncan, R. A., and M. A. Richards, Hot spots, mantle plumes, flood basalts, and true polar wander, Rev. Geophys., 29, 31-50, 1991.

Farrar, E., and D. C. Noble, Timing of late Tertiary deformation in the Andes of Peru, Geol. Soc. Am. Bull., 87, 1247-1250, 1976.

Fisher, R. A., Dispersion on a sphere, Proc. R. Soc London, 217, 295-305, 1953.

Fourtanier, E., F. Gasse, O. Bellier, M. G. Bonhomme, and I. Robles, Miocene non-marine diatoms from the Western Cordillera basins of northern Peru, Diatom Res., 8, 13-30, 1993.

Gephart, J. W., Topography and subduction geometry in the central Andes: Clues to the mechanics of noncollisional orogen, J. Geophys. Res., 99, $12,279-12,288,1994$

Gilder, S., S. Rousse, D. Farber, B. McNulty, T. Sempere, V. Torres, and O. Palacios, Post-middle Oligocene origin of paleomagnetic rotations in upper Permian to Lower Jurassic rocks from northern and southern Peru, Earth Planet Sci. Lett., 210, $233-248,2003$

Gutiérrez, M., Contribución al conocimiento micropaleontológico del Oriente Peruano, Anales III Congresco National de Geología, Bol. Soc. Geol. Peru, 49, 25-52, 1975.

Gutscher, M.-A., J. Malavieille, S. Lallemand, and J. Y. Collot, Tectonic segmentation of the north Andean margin: Impact of the Carnegie Ridge collision, Earth Planet. Sci. Lett., 168, 255-270, 1999.

Gutscher, M.-A., W. Spakman, H. Bijwaard, and E. R. Engdahl, Geodynamics of flat subduction: Seismicity and tomographic constraints from the Andean margin, Tectonics, 19, 814-833, 2000.

Hampel, A., The migration of the Nazca Ridge along the Peruvian active margin: A re-evaluation, Earth Planet. Sci. Lett., 203, 665-679, 2002.

Instituto de Geologia y Mineria, Mapa Geologico del Peru, scale 1:1000000, 1 sheet, Lima, 1975.

Isacks, B. L., Uplift of the Central Andean Plateau and bending of the Bolivian Orocline, J. Geophys. Res., 93, 3211-3231, 1988.

Jordan, T. E., B. L. Isacks, R. W. Allmendinger, J. A. Brewer, V. A. Ramos, and C. J. Ando, Andean tectonics related to geometry of the subducted Nazca plate, Geol. Soc. Am. Bull., 94(27), 341361, 1983.

Kirschvink, J. L., The least-square line and plane and the analysis of paleomagnetic data, Geophys. J. R Astron. Soc., 62, 699-718, 1980

Kley, J., and C. R. Monaldi, Tectonic shortening and crustal thickness in the central Andes: How good is the correlation?, Geology, 26, 723-726, 1998.

Lamb, S., Vertical axis rotation in the Bolivian orocline, South America: 1. Paleomagnetic analysis of Cretaceous and Cenozoic rocks, J. Geophys. Res., 106, 26,605-26,632, 2001.

Macedo-Sánchez, O., J. Surmont, C. Kissel, and C. Laj, New temporal constraints on the rotation of the Peruvian central Andes obtained from Paleomagnetism, Geophys. Res. Lett., 19, $1875-$ $1878,1992$.

Macharé, J., La marge continentale du Pérou: Régimes tectoniques et sédimentaires cénozoïques de l'avant-arc des Andes Centrales, Ph.D. Thesis, 391 pp., Univ. Paris XI, Orsay, France, 1987.

Macharé, J., T. Devries, J. Barron, and E. Fourtanier, Oligo-Miocene transgression along the Pacific margin of South America: New paleontological and geological evidence from the Pisco basin (Peru), Géodynamique, 3, 25-37, 1988.

Marocco, R., and C. de Muizon, Le bassin Pisco, bassin cénozoïque d'avant arc de la côte du Pérou central: 
Analyse géodynamique de son remplissage, Geodynamique, 3, 3-19, 1988

Mayes, C. L., L. A. Lawver, and D. T. Sandwell, Tectonic history and new isochron chart of the South Pacific, J. Geophys. Res., 95, 8543-8567, 1990.

McCaffrey, R., Oblique plate convergence, slip vectors, and forearc deformation, J. Geophys. Res., 97, $8905-8915,1992$.

McFadden, P. L., and F. J. Lowes, The discrimination of mean direction drawn from Fisher distribution, Geophys. J. R. Astron. Soc., 67, 19-33, 1981.

McFadden, P. L., and M. W. McElhinny, The combined analysis of remagnetization circles and direct observations in paleomagnetism, Earth Planet. Sci. Lett., $87,161-172,1988$.

McFadden, P. L., and M. W. McElhinny, Classification of the reversal test in paleomagnetism, Geophys. J. Int., 130, 725-729, 1990.

McNulty, B., and D. Farber, Active detachment faulting above the Peruvian flat slab, Geology, 30, 567570, 2002

McNulty, B. A., D. L. Farber, G. S. Wallace, R. Lopez, and O. Palacios, Role of plate kinematics and plateslip-vector partitioning in continental magmatic arcs: Evidence from the Cordillera Blanca, Peru, Geology, 26, 827-830, 1998

Mégard, F., The Andean orogenic period and its major structures in central and northern Peru, J. Geol. Soc. London, 141, 893-900, 1984.

Mercier, J. L., M. Sebrier, A. Lavenu, J. Cabrera, O. Bellier, J.-F. Dumont, and J. Macharé, Changes in the tectonic regime above a subduction zone of Andean type: The Andes of Peru and Bolivia during the Pliocene-Pleistocene, J. Geophys. Res., 97, 11,945-11,982, 1992.

Mitouard, P., C. Kissel, and C. Laj, Post-Oligocene rotations in southern Ecuador and northern Peru and the formation of the Huacabamba deflection in the Andean Cordillera, Earth Planet. Sci. Lett., 98, 329-339, 1990.

Mitouard, P., C. Laj, T. Mourier, and C. Kissel, Paleomagnetic study of an arcuate fold belt developed on a marginal orogen: The Cajamarca deflection, northern Peru, Earth Planet. Sci. Lett., 112, 41 52, 1992.

Montoya, M., W. García, and J. Caldas, Geologia de los cuadrangulos de Lomitas, Palpa, Nasca y Puquio; Hojas: 30-l, 30-m, 30-n y 30-ñ, Bol. Inst. Geol. Min. Metal., Ser. A, Carta Geol. Nac. Rep., 100 pp., Inst. Geol. Min. y Metal., Lima, Peru, 1994.

Mourier, T., La transition entre les Andes marginales et les Andes cordilleraines a ophiolites: Evolution sédimentaire, magmatique et struturale du relais de Huacabamba $\left(3^{\circ} \mathrm{S}\right.$ à $8^{\circ} \mathrm{S}$; Nord Pérou-Sud Equateur), Ph.D. thesis, 302 pp., Univ. Paris XI, Orsay, France, 1988.

Müller, R. D., J.-Y. Royer, S. C. Cande, W. R. Roest, and S. Maschenkov, New constraints on the Late Cretaceous/Tertiary plate tectonic evolution of the Carribean, in Caribbean Basins, Sedimentary Basins of the World Ser., vol. 4, edited by P. Mann, pp. 33-59, Elsevier Sci., New York, 1997.

Noble, D. C., and E. H. McKee, Comment on spatial distribution of earthquakes and subduction of the Nazca plate beneath South America, Geology, 5, 576-578, 1977.

Noble, D. C., E. H. McKee, T. Mourier, and F. Mégard, Cenozoic stratigraphy, magmatic activity, compressive deformation and uplift in northern Peru, Geol. Soc. Am. Bull., 102, 1105-1113, 1990.
Norabuena, E. O., J. A. Snoke, and D. E. James, Structure of subducting Nazca plate beneath Peru, J. Geophys. Res., 99, 9215-9226, 1994.

Norabuena, E. O., T. H. Dixon, S. Stein, and C. G. A Harrison, Decelerating Nazca-South America and Nazca-Pacific plate motions, Geophys. Res. Lett. 26, 3405-3408, 1999.

Norton, I. O., Plate motions in the North Pacific: The 43 Ma nonevent, Tectonics, 14, 1080-1094, 1995.

Patriat, P., and J. Segoufin, Reconstruction of the central Indian Ocean, Tectonophysics, 155, 211-234, 1988.

Pardo-Casas, F., and P. Molnar, Relative motion of the Nazca (Farallon) and South American plates since late cretaceous time, Tectonics, 6, 233-248, 1987.

Petford, N., and M. P. Atherton, Granitoid emplacement and deformation along a major crustal lineament: The Cordillera Blanca, Peru, Tectonophysics, 205 , $171-185,1992$.

Pilger, R. H., Plate reconstructions, aseismic ridges, and low angle subduction beneath the Andes, Geol. Soc. Am. Bull., 92, 448-456, 1981.

Pitcher, W. S., and E. J. Cobbing, Phanerozoic plutonism in the peruvian Andes, in Magmatism at a Plate Edge: The Peruvian Andes, edited by W. S. Pitcher et al., pp. 19-25, Halsted, New York, 1985.

Randall, D. E., A new Jurassic-Recent apparent polar wander path for South America and a review of central Andean tectonic models, Tectonophysics, 299, 49-74, 1998

Randall, D. E., G. K. Taylor, and J. Grocott, Major crustal rotations in the Andean margin: Paleomagnetic results from the Coastal Cordillera of northern Chile, J. Geophys. Res., 101, 15,783-15,798, 1996.

Randall, D. E., A. J. Tomlison, and G. K. Taylor, Paleomagnetically defined rotation from the Precordillera of northern Chile: Evidence of localized in situ fault-controlled rotations, Tectonics, 20, $235-$ 254, 2001.

Raymond, C. A., J. M. Stock, and S. C. Cande, Fast Paleogene motions of the Pacific hotspots from revised global plate circuits constraints, in The History and Dynamics of Global Plate Motions, vol. 121, Geophys. Monogr. Ser., edited by M. A Richards, R. R. Gordon, and R. D. van der Hilst, pp. 359-375, AGU, Washington, D. C., 2000.

Roperch, P., G. Hérail, and M. Fornari, Magnetostratigraphy of the Miocene Corque basin, Bolivia: Implication for the geodynamic evolution of the Altiplano during the late Tertiary, J. Geophys. Res., 104, 20,415-20,429, 1999.

Roperch, P., M. Fornari, G. Hérail, and G. V. Parraguez, Tectonic rotations within the Bolivian Altiplano: Implications for the geodynamic evolution of the central Andes during the late Tertiary, J. Geophys. Res., 105, 795-820, 2000.

Rousse, S., S. Gilder, D. Farber, B. McNulty, and V. R. Torres, Paleomagnetic evidence for rapid verticalaxis rotation in the Peruvian Cordillera ca. $8 \mathrm{Ma}$ Geology, 30, 75-78, 2002.

Sacks, I. S., The subduction of young lithosphere, J. Geophys. Res., 88, 3355-3366, 1983.

Sánchez, A., and I. Herrera, Geologia de los cuadrangulos de Moyobamba, Saposa y Janjui; Hojas: 13-j, 14-j y 15-j, Bol. Inst. Geol. Min. Metal., Ser. A, Carta Geol. Nac. Rep., vol. 122, 238 pp., Inst Geol. Min. y Metal., Lima, Peru, 1998.

Schultz, A., M. C. Rathert, S. D. C. Guerreiro, and W. Bloch, Paleomagnetism and rock magnetism of Fernando de Noronha, Brazil, Earth Planet. Sci. Lett., 79, 208-216, 1986.

Sébrier, M., A. Lavenu, M. Fornari, and J.-P. Soulas, Tectonics and uplift in the central Andes (Peru, Bolivia and Northern Chile) from Eocene to Present, Geodynamique, 3, 85-106, 1988.

Shackleton, R. M., A. C. Ries, M. P. Coward, and P. R. Cobbold, Structure, metamorphism and geochronology of the Arequipa Massif of coastal Peru, J. Geol. Soc. London, 136, 195-214, 1979

Somoza, R., Updated Nazca (Farallon)-South America relative motions during the last $40 \mathrm{My}$ : Implications for mountain building in the central Andean region, J. S. Am. Earth Sci., 11, 211-215, 1998.

Somoza, R., and A. Tomlinson, Paleomagnetism in the Precordillera of northern Chile $\left(22^{\circ} 30^{\prime} \mathrm{S}\right)$ : Implication for the history of tectonic rotations in the central Andes, Earth Planet. Sci. Lett., 194, 369-381, 2002.

Somoza, R., S. Singer, and B. Coira, Paleomagnetism of upper Miocene ignimbrites at the Puna: An analysis of vertical-axis rotations in the central Andes, J. Geophys. Res., 101, 11,387-11,400, 1996.

Tebbens, S. F., and S. C. Cande, Southeast Pacific tectonic evolution from early Oligocene to Present, J. Geophys. Res., 102, 12,061-12,084, 1997.

Tsunakawa, H., H. Tanaka, K. Amano, and M. Kono, Paleomagnetic study of late Miocene and early Pliocene rocks from southern Peru, central Andes, J. Geomag. Geoelectr., 39, 477-486, 1987.

Vidal, J. C., Geologia de los cuadrangulos de San Juan, Acari y Yauca. Hojas: 31-m, 31-n y 32-n, Bol. Inst. Geol. Min. Metal. Ser A, Carta Geol. Nac. Rep., vol. 30, 78 pp., Inst. Geol. Min. y Metal., Lima, Peru, 1978.

von-Huene, R., and S. Lallemand, Tectonic erosion along the Japan and Peru convergent margins, Geol. Soc. Am. Bull., 102, 704-720, 1990.

Watson, G. S., and R. J. Enkin, The fold test in paleomagnetism as a parameter estimation problem, Geophys. Res. Lett., 20, 2135-2137, 1993.

Wilson, J., L. Reyes, and J. Garayar, Geologia de los cuadrangulos de Pallasca, Tayabamaba, Corongo, Pomabamba, Carhuaz y Huari; Hojas: 17-h, 17-i, 18-h, 18-i, 19-g y 19-I, Bol. Inst. Geol. Min. Metal., Ser. A, Carta Geol. Nac. Rep., vol. 60, 64 pp., Inst. Geol. Min. y Metal., Lima, Peru, 1995.

Yáñez, G. A., C. R. Ranero, R. von Huene, and J. Díaz, Magnetic anomaly interpretation across the southern central Andes $\left(32^{\circ}-34^{\circ} \mathrm{S}\right)$ : The role of the Juan Fernández Ridge in the late Tertiary evolution of the margin, J. Geophys. Res., 106, 6325-6345, 2001 .

D. Farber, Lawrence Livermore National Laboratory, Livermore, CA 94550, USA.

S. Gilder, P. Patriat, and S. Rousse, Institut de Physique du Globe de Paris, Laboratoire de Paléomagnétisme, 4 place Jussieu, 75252 Paris Cedex 05, France. (gilder@ipgp.jussieu.fr)

B. McNulty, Earth Science Department, California State University, Dominguez Hills, Carson, CA 90747, USA.

T. Sempere, Institut de Recherche pour le Développement (IRD), apartado postal 18-1209, Lima 18, Peru.

V. Torres, Instituto Geológico, Minero y Metalúrgico (INGEMMET), Lima, 1470 Avenida Canadá, San Borja Lima 41, Peru. 